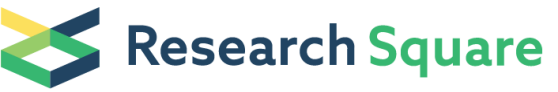

Preprints are preliminary reports that have not undergone peer review.

They should not be considered conclusive, used to inform clinical practice, or referenced by the media as validated information.

\section{Two-Step Targeted Drug Delivery via Proteinaceous Barnase-Barstar Interface and PLGA-Based Nano- Carrier}

\section{Victoria Shipunova ( $\nabla$ viktoriya.shipunova@phystech.edu )}

Moscow Institute of Physics and Technology National Research University: Moskovskij fiziko-tehniceskij institut nacional'nyj issledovatel'skij universitet https://orcid.org/0000-0001-6361-1042

\section{Elena N. Komedchikova}

Moscow Institute of Physics and Technology: Moskovskij fiziko-tehniceskij institut nacional'nyj issledovatel'skij universitet

\section{Anna S. Sogomonyan}

Shemyakin-Ovchinnikov Institute of Bioorganic Chemistry Russian Academy of Sciences: FBGUN Institut bioorganiceskoj himii im akademikov M M Semakina i U A Ovcinnikova Rossijskoj akademii nauk

\section{Alexey V. Stepanov}

Shemyakin-Ovchinnikov Institute of Bioorganic Chemistry Russian Academy of Sciences: FBGUN Institut bioorganiceskoj himii im akademikov M M Semakina i U A Ovcinnikova Rossijskoj akademii nauk

\section{Ekaterina D. Tereshina}

Shemyakin-Ovchinnikov Institute of Bioorganic Chemistry Russian Academy of Sciences: FBGUN Institut bioorganiceskoj himii im akademikov M M Semakina i U A Ovcinnikova Rossijskoj akademii nauk

\section{Mariia M. Belova}

Sirius University of Science and Technology

\section{Polina A. Kotelnikova}

Shemyakin-Ovchinnikov Institute of Bioorganic Chemistry Russian Academy of Sciences: FBGUN Institut bioorganiceskoj himii im akademikov M M Semakina i U A Ovcinnikova Rossijskoj akademii nauk

\section{Maxim P. Nikitin}

Moscow Institute of Physics and Technology: Moskovskij fiziko-tehniceskij institut nacional'nyj issledovatel'skij universitet

\section{Sergey M. Deyev}

Shemyakin-Ovchinnikov Institute of Bioorganic Chemistry Russian Academy of Sciences: FBGUN Institut bioorganiceskoj himii im akademikov M M Semakina i U A Ovcinnikova Rossijskoj akademii nauk

\section{Research Article}

\section{Keywords:}

Posted Date: February 18th, 2022 
DOI: https://doi.org/10.21203/rs.3.rs-1029355/v2

License: (c) (i) This work is licensed under a Creative Commons Attribution 4.0 International License. Read Full License 


\section{Abstract}

The conventional methods of treating cancer with chemo- and radiotherapy present plenty of serious problems, such as low therapeutic index and high systemic toxicity. The advanced cancer treatment strategies utilize nanoformulations of drugs that can enter a tumor due to the enhanced permeability and retention (EPR) effect. However, EPR fails in the treatment of several human diseases. Therefore, mainstream biomedical studies are focused on creating the drugs that would enter the tumor with higher effectiveness and require smaller doses for administration. A two-step targeted drug delivery system (DDS), involving the tumor pre-targeting with the first non-toxic module and subsequent targeting with the second complementary toxic module, is a solution for decreasing systemic toxicity. To meet the challenge, we have developed the two-step DDS mediated by the high-affinity binding of the barnase*barstar protein pair, one of the strongest known protein*protein complexes with $\mathrm{K}_{\mathrm{aff}}=10^{14} \mathrm{M}^{-1}$. Ribonuclease barnase (12 kDa) from Bacillus amyloliquefaciens and its natural inhibitor barstar (10 kDa) act as lego bricks linking the first and the second modules on the surface of the cancer cell. Artificial scaffold polypeptide DARPin9_29 (14 kDa) recognizing HER2 oncomarker was genetically fused with barstar to serve the first module of the developed two-step DDS. A therapeutic PLGA-based nanocarrier coupled to barnase was used as a second module. The PLGA nanoparticles were loaded with diagnostic dye, Nile Blue, and chemotherapeutic drug, doxorubicin. We showed that the two-step DDS increases the performance of chemotherapy-loaded nanocarriers both in vitro and in vivo compared to the one-step DDS. Namely, we showed that IC50 of doxorubicin delivered via two-step DDS is more than 100 times lower than that for one-step DDS: IC50 = $43 \pm 3$ nM for two-step DDS vs. IC50 = $4972 \pm 1965$ nM for one-step DDS. Moreover, the developed two-step DDS based on barnase*barstar showed superior efficiency in image-guided cancer therapy: HER2-positive tumors' treatment tests showed the tumor growth inhibition index TGI $=68.4 \%$ for one-step DDS and TGI $=94.9 \%$ for two-step DDS. The obtained results demonstrate the significant efficiency of two-step drug delivery over the classical one-step one. We believe that the obtained data will significantly change the direction of research in developing targeted anti-cancer drugs and promote the creation of new-generation cancer treatment strategies.

\section{Introduction}

Cancer is one of the most significant threats to humankind. In 2020 only, 19.1 million cases were registered, and this number is supposed to reach 28.4 million by 2040 . It is the second most frequent death cause, and the contribution of cancer to the mortality rate continues to grow [1]. Conventional cancer therapy strategies suffer from a lack of selectivity and low drug efficiency and are frequently associated with side effects, including cardiac dysfunction, cytopenia, infection, diarrhea, vomiting, and others $[2,3]$.

Significant efforts of researchers are aimed at developing methods to reduce the side effects of chemotherapeutic drugs $[4,5]$, to increase the effectiveness of therapeutic compounds already used in the clinic [6], as well as to develop fundamentally new methods of anticancer therapy [7-9]. Chemotherapyloaded nanoparticles capable of increasing the amount of therapeutic drug that reaches the tumor site 
and reducing the systemic toxicity provide encouraging solutions to the described problems. Moreover, drug encapsulation into the nanoparticle architecture can increase the bioavailability of the chemotherapeutic compound, extend the duration of action via bloodstream circulation prolongation, and can solve the problems associated with hydrophobicity and insolubility of drugs [10-16].

Several nanoparticle-based medications, such as PEGylated liposomal doxorubicin Caelyx [17], and liposomal formulation of daunorubicin and cytarabine VYXEOS [18], have already been approved by FDA for cancer treatment. However, despite the improved efficiency of such formulations, the delivery of nanoparticles occurs by passive transport through enlarged pores in the vascular endothelium of tumors known as the "enhanced permeability and retention" (EPR) effect [10]. However, it was shown that the EPR effect fails in big solid tumors for some patients. Therefore, it is critical to develop different approaches for the delivery of nanoparticles to cancer cells and monitor nanoparticles' fate in vitro and in vivo [1924].

One of the ways to implement targeted delivery is to modify the surface of nanoparticles with molecules binding specific cancer cell receptors [25]. This is a rapidly developing branch of biomedicine that has already demonstrated several promising results in clinical trials $[26,27]$. Various proteins, such as antibodies, transferrin, EGF, lectins, as well as protein-nucleic acid complexes, aptamers, and small molecules like folic acid and sugars, are traditionally used for targeted drug delivery [28]. Currently, small synthetic polypeptides (scaffold molecules) emerge as the most promising targeting compounds due to their remarkable affinity, stability, ease of biotechnological production, and the absence of immunomodulation in vivo [28-31].

A pre-targeting concept implying two-step delivery of therapeutic compounds to the tumor site is expected to provide significant systemic nanoparticle toxicity reduction and nanoparticle targeting abilities improvement [32]. This concept is based on the initial delivery of the first targeting non-toxic compound to specific cancer cells in a moderately high dose (thus realizing pre-targeting) followed by the delivery of a relatively small dose of a second toxic compound interacting with the first one in a key\&lock mode. A twostep drug delivery system (DDS) offers a series of benefits over the standard one-step DDS, such as 1) reduced toxicity for normal cells; 2) controlled penetration of a toxin into the tumor; 3 ) improved drug biodistribution; 4) reduction of the required dose of the drug [33]. The disadvantages of the currently available two-step DDSs consist in the immunogenicity of the components, possible competition with molecules in the bloodstream, and the expensive and time-consuming biotechnological production in mammals of the components of such DDSs [34, 35].

Here for the first time, we used barnase*barstar pair as a platform for two-step delivery of the oncotherapeutic compound. Ribonuclease barnase and its natural inhibitor barstar are small proteins (12 and $10 \mathrm{kDa}$ ) of bacterial origin that are not presented in mammals and possess an extremely high constant of binding $\left(K_{\text {aff }}=10^{14} \mathrm{M}^{-1}\right)$. We synthesized polymer PLGA nanoparticles, loaded them with the chemotherapeutic drug, doxorubicin, and the fluorescent dye, Nile Blue, and successfully modified the surface of nanoparticles with barnase. The barnase*barstar interface was used as lego bricks to link the 
toxic PLGA nanoparticles with scaffold protein DARPin9_29 recognizing the tumor marker HER2 on the cancer cell surface. DARPin9_29 was genetically fused with barstar to obtain Bs-DARPin9_29 protein capable of specifically targeting HER2-overexpressing cancer cells. We showed two-step effective labeling of HER2-overexpressing cancer cells with supramolecular structure PLGA-Bn*Bs-DARPin9_29 selfassembled on the cell surface. Moreover, we showed that two-step DDS is more efficient than one-step DDS both in vitro and in vivo for HER2-positive tumor treatment in BALB/c mice.

\section{Materials And Methods}

\section{Nanoparticle synthesis}

PLGA nanoparticles were synthesized by the double emulsion "water-oil-water" method, followed by solvent evaporation, according to a modified procedure developed by us earlier [36]. The first emulsion was obtained by adding $150 \mu \mathrm{L}$ of an aqueous solution of doxorubicin hydrochloride at a concentration of $2 \mathrm{~g} / \mathrm{L}$ to $300 \mu \mathrm{L}$ of PLGA at a concentration of $40 \mathrm{~g} / \mathrm{L}$ in chloroform and $50 \mu \mathrm{L}$ of Nile Blue Blue at various concentrations in chloroform, followed by sonication for $1 \mathrm{~min}$ at $40 \%$ mplitude and for $1 \mathrm{~min}$ at $60 \%$ mplitude using a $130 \mathrm{~W}$ ultrasonic disintegrator (Sonics) at $+4^{\circ} \mathrm{C}$. The second emulsion was created by mixing the first emulsion with $3 \mathrm{~mL}$ of $5 \%$ olyvinyl alcohol (PVA) solution in milliQ with the addition of 1 $\mathrm{g} / \mathrm{L}$ chitosan oligosaccharide lactate. The solution was sonicated for $1 \mathrm{~min}$ at $40 \%$ mplitude and $1 \mathrm{~min}$ at $60 \%$ mplitude at $+4^{\circ} \mathrm{C}$. The resulting solution was incubated with slow shaking for chloroform evaporation, then washed three times in PBS $\left(137 \mathrm{mM} \mathrm{NaCl}, 2.7 \mathrm{mM} \mathrm{KCl}, 4.77 \mathrm{mM} \mathrm{Na}_{2} \mathrm{HPO}_{4} \cdot 2 \mathrm{H}_{2} \mathrm{O}, 1.7\right.$ $\mathrm{mM} \mathrm{KH}_{2} \mathrm{PO}_{4}, \mathrm{pH}$ 7.4) by centrifugation, and resuspended in $300 \mu \mathrm{L}$ of PBS. The final concentration of nanoparticles was determined by drying at $+60^{\circ} \mathrm{C}$ and followed by weighing the dry residue.

\section{Electron microscopy}

Electron microscopy images of PLGA nanoparticles loaded with Nile Blue and doxorubicin were obtained with a MAIA3 (Tescan) microscope at an accelerating voltage of $15 \mathrm{kV}$. The samples were deposited onto a silicon wafer and then dried in the air. The resulting images were processed using ImageJ software to obtain a particle size distribution.

\section{Particle size and surface charge measurements}

The hydrodynamic sizes and $\zeta$-potential of PLGA nanoparticles loaded with Nile Blue and doxorubicin were determined in PBS at $25^{\circ} \mathrm{C}$ using a Zetasizer Nano ZS (Malvern Instruments Ltd.) analyzer.

\section{Nanoparticle tracking analysis}

Size of nanoparticles and its distribution was measured with nanoparticle tracking analysis. It was performed with an AstraTrace (Abisense, Russia) equipped with sCMOS scientific camera (PRIME 95B, Teledyne Photometrics, USA) and $405 \mathrm{~nm}$ violet laser with regulated power (24 mw power was set in the experiments). Nanoparticles were analysed in PBS. The videos were recorded at $6.6 \mathrm{fps}$ with $100 \mathrm{~ms}$ exposure time. 1000 frames were collected for each sample. The data were processed with AstraTrace 
software using trackpy [37] algorithm. Minimal length of trajectory was set to 5. Approximately 100 particles per frame we observed during the recording.

\section{Nanoparticles conjugation with proteins}

Barnase and barstar were expressed and purified as described by us previously [38]. PLGA nanoparticles were covalently modified with barnase or barstar proteins using EDC (1-ethyl-3-(3dimethylaminopropyl)carbodiimide hydrochloride) and sulfo-NHS (N-hydroxysulfosuccinimide sodium salt) as cross-linking agents through the formation of amide bonds between amino groups on the particle surface and protein carboxyl groups. $200 \mu \mathrm{g}$ of protein was activated by a 15 -fold molar excess of EDC and sulfo-NHS in 0.1 M MES (2-(N-morpholino)ethanesulfonic acid), pH 5.0 for 40 min at room temperature. Then protein was added to $1 \mathrm{mg}$ of PLGA nanoparticles in 1) borate buffer $-0.4 \mathrm{M} \mathrm{H}_{3} \mathrm{BO}_{3}$, $70 \mathrm{mM} \mathrm{Na}{ }_{2} \mathrm{~B}_{4} \mathrm{O}_{7} \cdot 10 \mathrm{H}_{2} \mathrm{O}, \mathrm{pH}$ 8.0, 2) $0.1 \mathrm{M} \mathrm{HEPES}$ (4-(2-hydroxyethyl)-1-piperazineethanesulfonic acid) $\mathrm{pH}$ 6.0 , and sonicated. The mixture was incubated for at least 5 hours at room temperature, periodically treated in an ultrasonic bath, and the unbound protein was washed off by triple centrifugation for 5 min at $8000 \mathrm{~g}$ in PBS with $1 \%$ SA (bovine serum albumin).

\section{Measurement of barnase activity}

The RNAse activity of barnase was investigated by the method of the acid-insoluble precipitate [39]. The protein solution or suspension of nanoparticles in $40 \mu \mathrm{L}$ of buffer $(0.125 \mathrm{M}$ Tris- $\mathrm{HCl}, \mathrm{pH} 8.5)$ was mixed with $160 \mu \mathrm{L}$ of yeast RNA at a concentration of $2 \mathrm{~g} / \mathrm{L}$ and incubated at $37^{\circ} \mathrm{C}$ for $15 \mathrm{~min}$. The reaction was terminated by the addition of $200 \mu \mathrm{L}$ of $0.625 \mathrm{~N} \mathrm{H}_{2} \mathrm{SO}_{4}$, and the mixture was incubated for $5 \mathrm{~min}$ at room temperature. Undigested RNA was separated by centrifugation at $14000 \mathrm{~g}$ for $15 \mathrm{~min}$ at room temperature. Optical density was measured at $\lambda=260 \mathrm{~nm}$ (OD260) corresponding to the concentration of free mononucleotides and proportional to the activity of the enzyme (ribonuclease). The inhibition of RNAse activity of barnase was measured similarly: nanoparticles conjugated with barstar were preincubated with $2.5 \mathrm{nM}$ barnase, and the enzymatic activity of the mixture was measured as described above.

\section{Fluorescent spectroscopy}

Excitation and emission spectra of PLGA nanoparticles loaded with Nile Blue and doxorubicin were obtained using an Infinite M100 Pro (Tecan) microplate reader. Nanoparticle suspension at a concentration of $10 \mu \mathrm{g} / \mathrm{mL}$ in $100 \mu \mathrm{L}$ of PBS was placed in a 96-well flat-bottomed plate. Excitation spectra were measured in the range from 350 to $675 \mathrm{~nm}$ (with the emission of $700 \mathrm{~nm}$ ), emission spectra from 675 to $850 \mathrm{~nm}$ (excitation wavelength $650 \mathrm{~nm}$ ). The stability of PLGA nanoparticles' fluorescence at a final concentration of $1 \mathrm{~g} / \mathrm{L}$ was measured several times during one week at an excitation of 570 and emission of $690 \mathrm{~nm}$ both in $\mathrm{H}_{2} \mathrm{O}$ and DMSO (dimethyl sulfoxide).

\section{Protein purification and conjugation to FITC}

Bn-DARPin9_29 was expressed and purified as described by us previously [40]. DARPin 9_29 fused with barstar was cloned into pET22b using barstar from the plasmid pIG-4D5-Barnase-Barstar [38] with the 
following protein sequence: (DARPin9_29)-([Gly $\left.{ }_{4} \mathrm{Ser}_{3}\right)$-(Barstar)-(His5-tag), thus making N-term of DARPin9_29 and C-term of barstar (through His-tag) available for chemical conjugation or other manipulations. Freshly transformed Escherichia coli BL1 (DE3) strain was grown in ZYM-5052 autoinduction medium ( $2 \%$ trytone, $1 \%$ yeat extract, $0.5 \%$ glyerol, $0.05 \%$ gluose, $0.02 \%$ lacose, $25 \mathrm{mM}$ $\mathrm{Na}_{2} \mathrm{HPO}_{4}, 25 \mathrm{mM} \mathrm{KH}_{2} \mathrm{PO}_{4}, 50 \mathrm{mM} \mathrm{NH}_{4} \mathrm{Cl}, 5 \mathrm{mM} \mathrm{Na}_{2} \mathrm{SO}_{4}, 2 \mathrm{mM} \mathrm{MgSO}_{4}$ [41]) containing $0.2 \mathrm{~g} / \mathrm{L}$ ampicillin. The culture was grown in the thermostatic shaker at $25^{\circ} \mathrm{C}$ and $200 \mathrm{rpm}$ overnight. Cells were harvested by centrifugation at $5000 \mathrm{~g}$ for $15 \mathrm{~min}$ at $4{ }^{\circ} \mathrm{C}$. Cell pellets were resuspended in lysis buffer $(20 \mathrm{mM} \mathrm{Na}-\mathrm{Pi}, 300$ $\mathrm{mM} \mathrm{NaCl}, \mathrm{pH} 7.4,50 \mu \mathrm{g} / \mathrm{mL}$ lysozyme) and then sonicated on ice. Cellular debris was removed by centrifugation at $30000 \mathrm{~g}$ at $+4^{\circ} \mathrm{C}$ for $2 \mathrm{~h}$. After the addition of imidazole $(20 \mathrm{mM})$, the supernatant was filtered through a $0.22 \mu \mathrm{m}$ membrane and applied onto a HisTrap HP, $1 \mathrm{~mL}$ column (GE Healthcare) equilibrated with $20 \mathrm{mM}$ sodium phosphate buffer ( $\mathrm{pH} 7.4), 300 \mathrm{mM} \mathrm{NaCl}$ and $20 \mathrm{mM}$ imidazole. The bound proteins were eluted with an imidazole step gradient $(50,75,100,150,200,250$, and $500 \mathrm{mM})$. The fractions were analyzed by $15 \%$ reducig SDS-PAGE.

Proteins were conjugated to FITC as follows: $100 \mu \mathrm{g}$ of protein in $90 \mu \mathrm{L}$ of PBS was rapidly mixed with 10 $\mu \mathrm{L}$ of FITC in DMSO and incubated overnight at room temperature with an 8-fold molar excess of FITC to protein. Proteins were purified from unreacted FITC molecules using a Zeba Spin Desalting Columns, 7k MWCO (Pierce) according to the manufacturer's recommendations.

\section{Cell culture}

Cell lines - human breast adenocarcinoma cells SK-BR-3, Chinese hamster ovary cells CHO, mouse mammary cells EMT6/P were cultured in DMEM medium supplemented with $10 \%$ fetal bovine serum, penicillin-streptomycin, and $2 \mathrm{mM} \mathrm{L-glutamine.} \mathrm{Cells} \mathrm{were} \mathrm{incubated} \mathrm{in} \mathrm{a} \mathrm{humidified} \mathrm{atmosphere} \mathrm{with} 5 \%$ $\mathrm{CO}_{2}$ at $37^{\circ} \mathrm{C}$. Cells were passaged when they reached $80-90 \%$ of the monolayer. To remove cells from the surface of the plastic, 2 mM EDTA (ethylenediaminetetraacetic acid) solution in PBS was used without trypsin addition (to avoid disruption of the integrity of cell receptors). Cell lines were maintained in culture for no more than two months, after which they were replaced with fresh frozen lines. For cell counting, a Countess (Invitrogen) automatic cell counter was used. For this, $5 \mu \mathrm{L}$ of $0.4 \%$ trypan blue, which stains only dead cells, was added to $5 \mu \mathrm{L}$ of cell suspension. The solution was pipetted and added to the slides for the automatic cell counting.

\section{Flow cytometry}

To determine the efficiency of cells labeling with FITC-modified proteins, the cell suspension was washed with PBS, resuspended in $300 \mu \mathrm{L}$ of PBS with $1 \%$ BSA at a concentration of $10^{6}$ cells $/ \mathrm{mL}$. Cells were labeled with proteins in a final concentration of $2 \mu \mathrm{g} / \mathrm{mL}$, washed, and analyzed in FL1 channel (excitation laser - $488 \mathrm{~nm}$, emission filter - 530/30 nm) using a BD Fortessa (BD) flow cytometer for TrastuzumabFITC and DARPin-based proteins. For the EMT6/P cell analysis, the Novocyte 2000R flow cytometer was used in the FL1 channel (excitation laser - $488 \mathrm{~nm}$, emission filter - 530/30 nm). 
To determine the specificity of targeted nanoparticles, the cell suspension was washed in PBS, resuspended in $300 \mu \mathrm{L}$ of PBS with $1 \% \mathrm{BSA}$ at a concentration of $10^{6}$ cells $/ \mathrm{mL}$. Cells were incubated with Bs-DARPin9_29 at concentrations $0,0.5$ and $2.5 \mu \mathrm{g} / \mathrm{mL}$ for $1 \mathrm{~h}$ at $+4^{\circ} \mathrm{C}$, washed from unbound protein by triple centrifugation. Then, PLGA-Bn conjugates were added to the cells, incubated for $15 \mathrm{~min}$, and washed from unbound nanoparticles by double centrifugation. Samples were analyzed using a BD Accuri C6 (BD) flow cytometer in the FL4 detection channel (excitation laser - $644 \mathrm{~nm}$, emission filter - 675/25 nm).

\section{Cytotoxicity assay}

Cytotoxicity of the synthesized nanoparticles and doxorubicin was investigated using a standard MTTtest. Cells were seeded in a 96-well plate at $10^{4}$ cells per well in $100 \mu \mathrm{L}$ of full DMEM with an addition of $10 \%$ FBS (fetal bovine serum) and cultured overnight. Then, test substances were added to the wells in $100 \mu \mathrm{L}$ of DMEM and incubated for $72 \mathrm{~h}$. Next, the medium was removed, and $100 \mu \mathrm{L}$ of MTT (tetrazolium dye 3-(4,5-dimethylthiazol-2-yl)-2,5-diphenyltetrazolium bromide) solution at a concentration of $0.5 \mathrm{~g} / \mathrm{L}$ in DMEM was added to the cells. The samples were incubated for $1 \mathrm{~h}$ at $37^{\circ} \mathrm{C}$, the MTT solution was removed, and $100 \mu \mathrm{L}$ of DMSO was added to the wells. The plate was moderately shaken until the formazan crystals were completely dissolved. The optical density of each well was measured with an Infinite M1000 Pro microplate analyzer (Tecan) at a wavelength of $570 \mathrm{~nm}$ and a reference wavelength of $630 \mathrm{~nm}$. The viability of cells was presented in percent in comparison to the untreated sample. All samples were performed in triplicate. IC50 was calculated using GraphPad Prism software.

\section{Red blood cell hemolysis}

Red blood cells (RBC) were isolated from mouse fresh whole blood, washed from serum with centrifugation, and resuspended in phosphate-buffered saline (PBS) to get a final $5 \%$ hematocrit level. The proteins under investigation were incubated with RBC for $2 \mathrm{~h}$ at room temperature. Next, red blood cells

were centrifuged for $3 \mathrm{~min}$ at $500 \mathrm{~g}$, and the absorbance of the supernatant was measured. As the positive control (equal to complete lysis), the sample of RBC lyzed with $\mathrm{H}_{2} \mathrm{O}$ was used. As the negative control (= spontaneous lysis), the sample of RBC incubated with PBS was used. The quantity of the released hemoglobin in the samples was measured at $540 \mathrm{~nm}$ and further presented in percent from the optical density of samples lyzed with $\mathrm{H}_{2} \mathrm{O}$ (equal to full lysis).

\section{Agglutination study}

The hemagglutination study was performed on 96-well U-shaped plates. The fresh whole blood was twice washed with PBS with $1 \%$ BSA and resuspended to get a final $1 \%$ concentration of RBC. The proteins under investigation were then added to the RBC samples, and $40 \mu \mathrm{L}$ of the sample was then placed into the well of 96 -well plate. The samples were incubated for $1 \mathrm{~h}$ at room temperature. The RBC sample without proteins was used as negative control (as the absence of agglutination). For the positive control, the sample of RBC was incubated with rat anti-mouse RBC IgG (TER-119, $50 \mu \mathrm{g} / \mathrm{mL}$ ) for $10 \mathrm{~min}$, washed from non-bound antibodies. Next, a secondary goat anti-rat antibody was added to get a final $10 \mu \mathrm{g} / \mathrm{mL}$ IgG concentration. This sample with antibody-mediated agglutination was used as the positive control. 
When the agglutination occurs, the red blood cells do not form a spot on the well bottom, forming a film over the surface of the well.

\section{Immunogenicity study}

For the immunogenicity study, female BALB/c mice (18-22 g) were purchased from Puschino Animal Facility and maintained at Vivarium of Institute of Bioorganic Chemistry (IBCh RAS).

To purify proteins produced in E. coli from lipopolysaccharides, High Capacity Endotoxin Removal Spin Columns, $0.5 \mathrm{~mL}$ (Pierce) were used according to the protocol recommended by the manufacturer. For all manipulations, we used laboratory plastic marked "sterile" and "non-pyrogenic". 10 min before protein injection, animals were anesthetized with a mixture of Zoletil (Virbac, France) and Rometar (Bioveta, Czech Republic) at a dose of 25/5 mg/kg. On 1, 3, 5, 7, 9, 11, 13 days, mice were injected intraperitoneally with $10 \mu \mathrm{g}$ of proteins in $100 \mu \mathrm{L}$ of sterile pyrogen-free PBS. Before and 21 days after the first injection, the blood sample was taken, and the serum was isolated by centrifugation for $10 \mathrm{~min}$ at $400 \mathrm{~g}$ at $15^{\circ} \mathrm{C}$ after a 30 min incubation at room temperature for blood clotting. The amount of protein-specific antibodies was analyzed by enzyme-linked immunosorbent assay.

\section{ELISA}

The protein under investigation (barnase or barstar) in an amount of $0.5 \mu \mathrm{g}$ per well was sorbed overnight at $+4^{\circ} \mathrm{C}$ in $100 \mu \mathrm{L}$ of carbonate buffer $\left(4 \mathrm{mM} \mathrm{Na}_{2} \mathrm{CO}_{3}, 50 \mathrm{mM} \mathrm{NaHCO}_{3}, \mathrm{pH}\right.$ 9.2) in the wells of 96-well ELISA plates. Then the wells were washed twice with $200 \mu \mathrm{L}$ of PBS with $0.05 \%$ Tween-20. Diluted mouse blood serum in $100 \mu$ PBS with 1\% BSA was then added to the wells, incubated for $1 \mathrm{~h}$ at room temperature. Then the wells were washed twice with $200 \mu \mathrm{L}$ of PBS with $0.05 \%$ Tween-20. The wells were added with $100 \mu \mathrm{L}$ of anti-mouse antibodies with alkaline phosphatase in $100 \mu \mathrm{L}$ of PBS with $1 \%$ BSA and incubated for $1 \mathrm{~h}$ at room temperature. Then the wells were washed three times with $200 \mu \mathrm{L}$ of PBS with $0.05 \%$ Tween-20. Then p-nitrophenyl phosphate was added to the wells at a concentration of $10 \mathrm{~g} / \mathrm{L}$ in glycine buffer $\left(0.1 \mathrm{M}\right.$ glycine, $1 \mathrm{mM} \mathrm{MgCl}_{2}, \mathrm{pH}$ 2). The reaction was stopped with a $0.1 \mathrm{M} \mathrm{NaCl}$ solution, $\mathrm{pH} 10.4$, and the absorption of the samples was recorded at a wavelength of $405 \mathrm{~nm}$.

\section{EMT-HER2 cells}

The DNA fragments coding for the full-size human HER2 receptor (P04626) were synthesized (GeneCust) and cloned into the pLV2 lentiviral vector (Clontech) under the control of the EF1a promoter. HEK293T cells were co-transfected with one of the viral plasmids and the set of packaging 3rd generation plasmids (Addgene). Supernatants containing viruses were collected at $48 \mathrm{~h}$ post-transfection. The titer of lentivirus preparations was determined using Lenti-X p24 ELISAs (Clontech). EMT6/P cells were transduced with asobtained lentiviruses and $48 \mathrm{~h}$ after, cells were seeded onto a 96-well plate at 1 cell per well to get single colonies. Single colonies were further grown in $25 \mathrm{~cm}^{2}$ flasks and then analyzed with flow cytometry for the expression of the HER2 receptor. The cell line with moderate receptor expression was selected for further in vivo experiments. 


\section{Tumor-bearing mice}

Female BALB/c mice (18-22 g) were injected with $4 \cdot 10^{6}$ EMT-HER2 cells in $100 \mu \mathrm{L}$ of full culture medium in the right flank to create tumors. The tumor size was measured with a caliper using the formula $\mathrm{V}=$ width ${ }^{2} \times$ length $/ 2$.

\section{Cryosections}

Mice were sacrificed with cervical dislocation, and cryosections of tumor tissue were obtained using FSE cryostat (Thermo). Cryosections were fixed with 4\% paraformaldehyde, permeabilized with PBS supplemented with $0.01 \%$ TritonX-100, and labeled with Hoechst33342 and anti-HER2 IgG-FITC in PBS supplemented with $1 \%$ BSA for 30 min followed with PBS washing and mounted using VECTASHIELD Antifade Mounting Medium (Vector Laboratories).

\section{Confocal laser scanning microscopy}

SK-BR-3 and $\mathrm{CHO}$ cells were seeded on 96 -well plates at $10 \cdot 10^{3}$ cells per well, cultured overnight, and incubated with $2 \mu \mathrm{g} / \mathrm{mL}$ DARPin9_29-FITC or Trastuzumab-FITC and Hoechst33342 (1 $\mu \mathrm{g} / \mathrm{mL})$ in PBS with $1 \%$ BSA for 30 min at $+4^{\circ} \mathrm{C}$. Next, cells were washed from non-bound proteins and imaged with LSM 980 (Zeiss) confocal microscope at the following conditions: excitation laser - $488 \mathrm{~nm}$, emission $492-550$ $\mathrm{nm}$ for FITC detection, and excitation laser - 405 nm, emission 410-520 nm for Hoechst33342 detection.

EMT6/P and EMT-HER2 cells were labeled Trastuzumab-FITC at $2 \mu \mathrm{g} / \mathrm{mL}$ in PBS with $1 \%$ BSA for 30 min at $+4^{\circ} \mathrm{C}$. Confocal microscopy images of cells were obtained with an FV3000 laser-scanning confocal microscope (Olympus Optical Co Ltd, Tokyo, Japan) using LUCPLFLN 20x objective (20x magnification, 0.45 numerical aperture) with $488 \mathrm{~nm}$ laser and GaAsP detector (542 V) (500-600 nm).

Confocal microscopy images of cryosections were obtained with an FV3000 laser-scanning confocal microscope (Olympus Optical Co. Ltd., Tokyo, Japan) using UPLSAPO 40×2 objective (40× magnification, 0.95 numerical aperture) with $405 \mathrm{~nm}$ laser and GaAsP detector (447 V) (430-470 nm) for Hoechst33342 detection and $488 \mathrm{~nm}$ laser and GaAsP detector (545 V) (500-600 nm) for FITC detection.

In vivo imaging

In vivo imaging was performed with a LumoTrace FLUO bioimaging system (Abisense LLC, Sochi, Russia) as follows: mice were anesthetized $4 \mathrm{~h}$ after the injection of nanoparticles and imaged with fluorescence excitation at $\lambda_{\text {ex }}=730 \mathrm{~nm}$ and $780 \mathrm{~nm}$ long-pass filter.

\section{Results}

\section{Synthesis and characterization of polymer nanoparticles based on poly-(D, L-lactic-co-glycolic acid)}


Poly-(D, L-lactic-co-glycolic acid) nanoparticles (PLGA) possessing both fluorescent and cytotoxic properties were synthesized by the double water-oil-water emulsion method, as shown in Figure 1.

Nile Blue ([9-(diethylamino)benzo[a]phenoxazin-5-ylidene] azanium sulfate, also known as Nile Blue A) was incorporated in the nanoparticles as a fluorescent dye that allows to track the particles inside cells and use them for diagnostic purposes. This dye is successfully used in a wide range of biological applications, such as gel electrophoresis, staining of histological sections, labeling of neutral lipids and fatty acids, and visualization of cancer cells [42]. Nile Blue is a biocompatible dye with absorption and emission maxima in the near-infrared optical window (635 and $674 \mathrm{~nm}$ in water solution, respectively), which makes it optimal for labeling target cells in vitro and in vivo.

Doxorubicin was incorporated into the nanoparticles that allow using them for therapeutic applications. Doxorubicin is an anthracycline antibiotic that causes cell death by the interaction with DNA and inhibition of topoisomerase II, which leads to suppression of nucleic acids synthesis, and by the formation of free radicals, that destroy cellular membrane and biomolecules $[43,44]$.

Nanoparticles were synthesized by the double emulsion "water-oil-water" method with subsequent evaporation of the solvent as shown in Figure 1.

The first emulsion was obtained by the addition of water doxorubicin solution to the solution of PLGA and Nile Blue in chloroform, followed by a short sonication. The second emulsion was obtained by the addition of the first emulsion to the PVA solution containing $1 \mathrm{~g} / \mathrm{L}$ of chitosan oligosaccharide lactate, followed by the second short sonication. After chloroform evaporation by the slow mixing, nanoparticles were centrifugated and resuspended in PBS.

The morphology of as-synthesized nanoparticles loaded with Nile Blue and doxorubicin was studied by scanning electron microscopy (MAIA3 microscope, Tescan) at an accelerating voltage of $15 \mathrm{kV}$ using an in-beam secondary electron detector. The received images (Fig. 2a) illustrate that synthesized PLGA nanoparticles are spherical monodisperse structures. Image processing with ImageJ software shows that the average size and standard deviation of nanoparticles are $218 \pm 59 \mathrm{~nm}$ (Fig. 2b). The hydrodynamic size of nanoparticles, measured by the dynamic light scattering method, was determined as $201 \pm 38 \mathrm{~nm}$ (Fig. 2c) thus completely corresponding to the value of the physical size of nanoparticles. These data indicate that nanoparticles preserved colloidal stability and did not form aggregates in saline solution. Moreover, visual observation showed that nanoparticles were stable for at least 6 months; further observations were not carried out. The $\zeta$-potential of nanoparticles, measured by the electrophoretic light scattering method, was $-1.64 \mathrm{mV}$ (Fig. $2 \mathrm{~d}$ ) thus slightly deviating from zero. Such surface charge at $\mathrm{pH}$ 7.4 was due to the presence of both negatively charged carboxyl groups $-\mathrm{COOH}$ (within the composition of PLGA) and positively charged amino groups $-\mathrm{NH}_{2}$ (within the composition of chitosan) on the surface of the nanoparticles.

The effective incorporation of the fluorescent dye Nile Blue was investigated by fluorescence spectroscopy by measuring the excitation and fluorescence emission spectra of nanoparticles. The 
excitation spectra were measured in the range from 350 to $675 \mathrm{~nm}$ (with emission at $700 \mathrm{~nm}$ ). Four PLGA nanoparticles with different Nile Blue concentrations used in the synthesis were investigated. The excitation spectra (Fig. 2e) and emission spectra (Fig. 2f) demonstrate that the most effective Nile Blue concentration during the synthesis is $1.7 \mathrm{~g} / \mathrm{L}$, the further scaling up of Nile Blue concentration leads to the decrease in fluorescence intensity. It is most probably caused by non-fluorescent $\mathrm{H}$-aggregates formation with an absorption shifted to the blue region of the spectrum. The nanoparticle tracking analysis showed the size of nanoparticles to be equal to $230.7 \mathrm{~nm}, 227.0 \mathrm{~nm}, 188.5 \mathrm{~nm}, 180.5 \mathrm{~nm}$ for particles with $5 \mathrm{~g} / \mathrm{L}$, $1.7 \mathrm{~g} / \mathrm{L}, 0.5 \mathrm{~g} / \mathrm{L}, 0.18 \mathrm{~g} / \mathrm{L}$ of Nile Blue used in the synthesis, respectively (Fig. S1). These data show that the Nile Blue concentration significantly affects the nanoparticle size and must be taken into account when developing scalable methods for the synthesis of nanoparticles for in vivo injection.

\section{Barnase*barstar protein interface for the targeted two-step delivery of PLGA particles to HER2- overexpressing cancer cells in vitro}

One of the central problems of modern chemotherapy is its relative non-specificity. The surface of nanoparticles is modified with targeting molecules to deliver them to specific cells and tissues. This can help to reduce non-specific toxicity of drugs to normal non-transformed cells. To make this kind of modification universal for any target on the cell surface and include the possibility to "cancel the action on demand", we propose to mediate the interaction between toxic nanoparticles and molecules recognizing cancer cells using protein adaptors, the barnase*barstar protein pair. Barstar (10 kDa) is a natural inhibitor of bacterial ribonuclease barnase $(12 \mathrm{kDa})$ [38]. The $\mathrm{N}$ - and C-terms of both proteins are available for chemical conjugation and genetic engineering and are not located in the active site of both enzymes [38, 40].

We used scaffold protein DARPin9_29 that recognizes the receptor HER2 on the surface of cancer cells with high affinity $\left(K_{D}=3.8 \mathrm{nM}\right)$ for the targeted delivery of synthesized polymer PLGA nanoparticles to cancer cells. This modular DDS based on PLGA nanoparticles, protein adaptors barnase*barstar, and scaffold proteins is schematically illustrated in Figure 3.

The surface of the nanoparticles was modified by one of the components of the pair - Figure 3 shows PLGA nanoparticles covalently modified with barnase. During the pre-targeting process, Bs-DARPin9_29 bifunctional protein was added to the cells with HER2 overexpression leading to the selective binding of the anti-HER2 molecule to the cancer cell surface. Next, self-assembly with the second component of the pair was carried out, namely, with PLGA nanoparticles conjugated with barnase. The resulting supramolecular structure selectively interacted with the cells with overexpression of receptor HER2: DARPin9_29 mediated the internalization of PLGA nanoparticles in the cells, while chemotherapy drug induced cell death.

Chemical modification of PLGA nanoparticles was carried out by using the sodium salt of 1-ethyl-3- (3dimethyl aminopropyl) carbodiimide, EDC, and the sodium salt of N-hydroxysulfosuccinimide, sulfo-NHS, as cross-linking agents through the formation of amide bonds between the carboxyl groups of proteins and amino groups on the surface of nanoparticles. The amino groups are presented on the surface of 
nanoparticles because of chitosan oligosaccharide lactate surface stabilization. In the first stage of the reaction, proteins were activated with EDC/sulfo-NHS mixture in an acidic buffer with $\mathrm{pH} 5.0$, then nanoparticles were added to the buffer with $\mathrm{pH} 6.0$ or $\mathrm{pH}$ 8.0.

The efficacy of conjugation of PLGA nanoparticles to barnase was measured by the enzymatic ability of conjugated nanoparticles, namely, their ability to hydrolyze RNA due to the presence of functionally active barnase on the nanoparticle surface. The measurement was performed by the commonly used method of the acid-insoluble precipitate [39]. First, the solution of conjugated PLGA nanoparticles was mixed with yeast RNA and incubated at $37^{\circ} \mathrm{C}$ to digest RNA. Then, the reaction was stopped by the addition of sulfuric acid, and the supernatant containing uncleaved RNA was separated by centrifugation. The optical density of the solution corresponding to the concentration of free mononucleotides and proportional to the activity of the enzyme was measured by the microplate reader in 96-well UV-Vis transparent plates. The value of sample absorbance at $260 \mathrm{~nm}$ is proportional to the concentration of free mononucleotides in the solution, thus reflecting the RNAse activity of the tested sample, either ribonuclease activity of the tested proteins or nanoparticles conjugated to proteins.

The efficiency of conjugation of PLGA nanoparticles to barstar was measured in a similar way by testing the ability of barstar to inhibit the RNAse activity of free barnase added to the sample of nanoparticles. Nanoparticles conjugated with barstar were pre-incubated with barnase, and the enzymatic activity of the mixture was measured as described above.

First, we tested the functional activity of free barnase and barstar before conjugation to nanoparticles. The enzymatic activity of free barnase and barstar proteins is shown in Figure 4a. The purple curve corresponds to the activity of the free barnase and has a concentration-dependent manner achieving saturation. As a positive control in the experiment directed towards the investigation of the enzymatic activity of PLGA nanoparticles conjugated with barnase, a sample of free barnase at a concentration of $2.5 \mathrm{nM}$ was used. This point corresponds to the middle of the linear range of the barnase enzymatic activity curve. The enzymatic activity of barstar, namely the ability to inhibit barnase, was investigated similarly by its pre-incubation with $2.5 \mathrm{nM}$ of barnase (green curve in Figure $4 \mathrm{a}$ ) and measuring the enzymatic activity of the sample. As a positive control in the investigation of the enzymatic activity of PLGA nanoparticles conjugated with barstar, a sample with barstar at a concentration of $15 \mathrm{nM}$ (+ barnase $2.5 \mathrm{nM}$ ) was used.

We obtained three types of PLGA nanoparticles modified with barnase by three different methods: i) carbodiimide conjugation at $\mathrm{pH} 8.0$, ii) carbodiimide conjugation at $\mathrm{pH} 6.0$, iii) non-covalent protein adsorption on the particle surface. For the modification via protein adsorption, PLGA nanoparticles were incubated with barnase or barstar in PBS at the same concentrations used for covalent coupling for $5 \mathrm{~h}$ at room temperature.

Data presented in Figure $4 \mathrm{~b}$ indicate that the highest efficiency of modification of PLGA nanoparticles with barnase is achieved during chemical conjugation at $\mathrm{pH}$ 6.0. Similar data were obtained for PLGA nanoparticles conjugated with barstar: the highest inhibition of the barnase activity is achieved for 
conjugates obtained at $\mathrm{pH}$ 6.0. Therefore, the possibility of obtaining functionally effective PLGA nanoparticles in terms of enzymatic activity with both barnase and barstar has been demonstrated.

\subsection{Targeted delivery of polymer PLGA nanoparticles to the HER-overexpressing cells in vitro}

We demonstrated the efficiency of two-step DDS vs. one-step DDS for the creation of targeted nanostructures for delivery to the cancer cells for their selective destruction. Namely, conjugates of PLGA nanoparticles with barnase, PLGA-Bn, were obtained and self-assembled on the cancer cell surface using barstar fused with DARPin9_29. Thus, supramolecular structures PLGA-Bn*Bs-DARPin9_29 were assembled on the cell surface using pre-targeting concept via Bs-DARPin9_29 protein and subsequent binding with PLGA-Bn. These structures were delivered to the cells overexpressing receptor HER2.

For the in vitro experiments, we selected two cell lines with various levels of HER2 expression, namely SKBR-3 and CHO cells. SK-BR-3 is a mammary adenocarcinoma cell line with overexpression of HER2 (about $10^{6}$ receptors per cell), while $\mathrm{CHO}$, Chinese hamster ovary cells, do not express any receptor of the EGFR family. Expression of HER2 receptor on these cells was confirmed by confocal microscopy (Fig. $5 \mathrm{a}$ ) and by flow cytometry (Fig. 5b) by imaging cells with fluorescence-labeled full-length antibody against HER2 Trastuzumab-FITC. Also, the binding of DARPin9_29 was confirmed by cell labeling with DARPin9_29FITC (Fig. 5b). Data from confocal microscopy and cytometry assays presented in Figure 5a,b indicate that SK-BR-3 cells do express HER2 and are effectively labeled with full-length anti-HER2 antibody Trastuzumab and anti-HER2 scaffold protein DARPin9_29.

The functional activity of DARPin within the composition of fusion proteins with barnase and barstar Bn-DARPin9_29 and Bs-DARPin9_29 was confirmed by flow cytometry (Fig. 5b) by labeling cells with HER2 receptor overexpression. It was demonstrated that the presence of barnase and barstar in fusion protein does not affect the interaction of DARPin9_29 with HER2-positive cells. Thus, both components of the barnase*barstar protein pair did not influence the functional activity of recognizing scaffold DARPin9_29 and can be used as adaptor proteins mediating two-step targeted drug delivery.

The functional polymer PLGA nanostructures were used for selective targeting of cells with HER2 overexpression. Labeling was carried out by the two-stage targeted delivery method. At the first stage, cells were incubated in suspension with Bs-DARPin9_29 in two different concentrations, followed by washing from unbound protein. Next, the cells were labeled by PLGA-Bn, followed by washing from unbound particles. The binding between nanostructures and cells was estimated by flow cytometry with excitation with a $640 \mathrm{~nm}$ laser in the fluorescence channel corresponding to the Nile Blue fluorescence.

The data presented in Fig. 5c indicates highly effective labeling of HER2-overexpressing cells by polymer PLGA nanostructures, assembled on the cells' surface, PLGA-Bn*Bs-DARPin9_29. Non-specific labeling of cells by PLGA-Bn conjugates is not observed, and binding of PLGA-Bn*Bs-DARPin9_29 with cells has a concentration-dependent manner. With an increase in the concentration of Bs-DARPin9_29 by 5 times from $0.5 \mu \mathrm{g} / \mathrm{mL}$ to $2.5 \mu \mathrm{g} / \mathrm{mL}$, the median fluorescence intensity of the cell population increases by $17551 / 2904=6$ times. 


\section{Cytotoxicity of targeted supramolecular structures PLGA Bn*Bs DARPin9_29}

The synthesized PLGA polymer nanoparticles contain a fluorescent dye, Nile Blue, and a chemotherapeutic drug, doxorubicin, which induces cell death via apoptosis.

The efficient incorporation of doxorubicin was investigated by fluorescent spectroscopy on nanoparticles that do not contain Nile Blue. Nanoparticles were solved in DMSO and then fluorescence was measured using a fluorescence calibration curve for doxorubicin samples in the same solutions (Fig. $5 \mathrm{~d}$ ). The measurement of the fluorescence of the samples showed that doxorubicin incorporation was $0.9 \mathrm{nmol}$ doxorubicin per $1 \mathrm{mg}$ of nanoparticles. The stability of fluorescence of the synthesized nanoparticles loaded with doxorubicin and Nile Blue was investigated for 1 week both in water and DMSO, the data presented in Fig. 5e confirm that the particles do not bleach during storage at room temperature in a plastic tube without light protection at least for one week.

The cytotoxicity of two-step DDS PLGA-Bn*Bs-DARPin9_29 was investigated by standard MTT-test three days after adding the nanostructures in different concentrations to the HER2-overexpressing cells. The therapeutic efficacy of two-step DDS was compared with i) one-step DDS, namely, PLGA directly conjugated to DARPin9_29, ii) free doxorubicin, which was added to the cells under similar conditions, iii) non-targeted PLGA nanoparticles loaded with doxorubicin. The results of the cytotoxicity study are presented in Fig. 5f, which shows the molar concentration of free doxorubicin and molar concentration of doxorubicin incorporated inside PLGA particles in different formulations.

Half-maximal inhibitory concentration (IC50) calculated for different formulations was found to be:

i. IC50 = $43 \pm 3 \mathrm{nM}$ for doxorubicin delivered via two-step DDS;

ii. IC50 = $4972 \pm 1965 \mathrm{nM}$ for doxorubicin delivered via one-step DDS;

iii. IC50 = $441 \pm 61 \mathrm{nM}$ for free doxorubicin;

iv. IC50 = $134 \pm 51.2 \mathrm{nM}$ for doxorubicin delivered via non-targeted PLGA.

Consequently, the incorporation of doxorubicin in the composition of targeted two-step DDS nanoparticles decreases its IC50 by 10.3 times vs. free doxorubicin and more than 100 times $v s$. one-step DDS. At the same time, cells exposed to non-targeted PLGA nanoparticles or one-step DDS were not affected by the cytotoxic properties of doxorubicin loaded inside nanoparticles and survived by more than $82 \%$ even at the highest concentrations of PLGA, namely $1 \mathrm{~g} / \mathrm{L}$ (Fig. 5f). Hence, including a chemotherapeutic drug in the composition of polymer PLGA nanoparticles assembled on the surface of the cancer cells via barnase*barstar interface significantly decreases the concentration of chemotherapeutic drug doxorubicin, needed to receive the same cytotoxic effect in comparison with either doxorubicin in molecular form or one-step DDS.

Barnase and barstar hemotoxicity study 
During the development of therapeutic drugs, in particular of a protein origin, one of the key biocompatibility parameters is the hemotoxicity and immunogenicity of a given drug. These studies should be carried out to assess the possibility of multiple administrations of the drug and/or repetition of the course of therapy. In order to assess the possible risks associated with systemic repeated administration of structures containing the proteins barnase and barstar, the hemotoxicity and immunogenicity of these proteins were investigated separately.

To study hemotoxicity, in particular, possible hemolysis and hemagglutination, mouse erythrocytes were incubated with proteins: barnase or barstar at various concentrations. The amount of released hemoglobin was assessed by measuring the absorbance at a wavelength of $540 \mathrm{~nm}$, and the value obtained was expressed as a percentage of the absorbance of the positive control sample (complete lysis), as described in detail in the Methods section. It was shown that all tested proteins in a wide range of concentrations do not cause hemolysis of erythrocytes (Fig. 6a).

Hemagglutination studies were performed in U-shaped 96-well plates. For this, mouse red blood cells were incubated with proteins: barnase or barstar at various concentrations in U-shaped plates. In the case of hemagglutination, blood cells did not settle at a point in the center of the well and formed a film over the entire surface. It was shown that all tested proteins in a wide range of concentrations do not cause hemagglutination (Fig. 6a).

\section{Immunogenicity study of barnase and barstar}

To study the immunogenicity of barnase and barstar BALB/c mice (18-22 g) were injected intraperitoneally with $10 \mu \mathrm{g}$ of proteins in $100 \mu \mathrm{L}$ of sterile pyrogen-free PBS on study days $1,3,5,7,9,11$, 13. Proteins were pre-purified from lipopolysaccharides using Pierce High Capacity Endotoxin Removal Spin Columns, $0.5 \mathrm{~mL}$. A group of animals that were injected with PBS without proteins was used as a "negative" control. As a "positive" control, was used a group of animals that were injected with proteins according to the same scheme, but at the same time, on day 1 , a protein was injected in a mixture with 50 $\mu \mathrm{L}$ of complete Freund's adjuvant, on day 13 - mixed with $50 \mu \mathrm{L}$ of incomplete Freund's adjuvant. Before and 21 days after the first injection, the blood samples were taken, serum was isolated, and the amount of protein-specific antibodies in the serum was analyzed in the enzyme-linked immunosorbent assay format as described in the Methods section.

The results of the enzyme-linked immunosorbent assay, namely the amount of antibodies depending on the serum dilution for mice injected with the proteins barnase or barstar for the main and control groups are shown in Fig. $6 \mathrm{c}$. The data presented in Fig. $6 \mathrm{c}$ indicate the absence of a specific immune response in mice for the tested proteins on day 21 after the first injection even with the "boosting" the immune response by injecting proteins in a mixture with complete and then incomplete Freund's adjuvant. At the same time, the weight of the animals (Fig. 6b) did not change significantly throughout the entire experiment for all experimental groups. The obtained data indicate the possibility of multiple administration of the studied proteins without serious risks associated with the specific B-cell immune response of the organism. 
In vivo bioimaging

To compare the effectiveness of targeted two-step and one-step therapy mediated by scaffold polypeptides DARPins, the following in vivo tests were performed. For the one-step targeted delivery, the injection of the conjugate of PLGA nanoparticles with DARPin9_29 was used. For the two-step targeted delivery in vivo, the injection of DARPin9_29-Bs followed by the injection of the conjugate of PLGA-Bn with barnase was used.

To assess the effectiveness of these two approaches for tumor treatment, we developed a mouse tumor model with HER2 overexpression. For this, mouse mammary cancer cells EMT6/P were transduced with transmembrane receptor HER2 via lentiviral transfection, and the single clone of the resultant cells was selected and grown. The HER2 expression on as-obtained cells, EMT-HER2, was confirmed with flow cytometry (Fig. 6d) and confocal laser scanning microscopy (Fig. 6e). Next, these cells were s.c. injected into the right flank of BALB/c mice in full culture medium and after tumor size reaches $\sim 200 \mathrm{~mm}^{3}$ the cryosections of the tumor were performed and stained with anti-HER2 lgG and Hoeschst33342 (Fig. $6 \mathrm{f}$ ). Thus we show that these cells stably express receptor HER2 both in vitro and in vivo in immunocompetent mice $(B A L B / c)$.

As-obtained EMT-HER2 tumors were used in the bioimaging and tumor growth inhibition studies. Mice were divided into three groups that received the following injections: 1) i.v. injection of $500 \mu \mathrm{g}$ of the conjugate of PLGA nanoparticles with DARPin9_29 on days 8 and 10 of the treatment, 2) i.v. injection of $150 \mu \mathrm{g}$ of DARPin9_29-Bs and 2h later i.v. injection of $500 \mu \mathrm{g}$ of the conjugate of PLGA nanoparticles with Bn on days 8 and 10 of the treatment, 3 ) the control group received no treatment.

The accumulation of PLGA nanoparticles in the tumor area was monitored $4 \mathrm{~h}$ after the nanoparticles injection with the Lumotrace FLUO bioimaging system (Fig. 6h). We showed that the two-step targeted drug delivery is much more effective in terms of nanoparticle accumulation in tumors for bioimaging purposes.

\section{In vivo therapy}

To evaluate the efficacy of two-step targeted delivery in comparison with one-step delivery for the tumor treatment, we measured the tumor size in all experimental groups. The tumor growth dynamics are presented in Fig. 6g.

The tumor growth inhibition indexes at 21 day calculated as \%TGI $=\left(1-\left\{\mathrm{T}_{\mathrm{t}} / \mathrm{T}_{0}\right\} /\left\{\mathrm{C}_{\mathrm{t}} / \mathrm{C}_{0}\right\}\right) /\left(1-\left\{\mathrm{C}_{0} / \mathrm{C}_{\mathrm{t}}\right\}\right) \times$ 100 where $T_{t}=$ median tumor volume of treated at time $t, T_{0}=$ median tumor volume of treated at time 0 , $\mathrm{C}_{\mathrm{t}}=$ median tumor volume of control at time $\mathrm{t}$ and $\mathrm{C}_{0}=$ median tumor volume of control at time 0 were found to be equal to $\mathrm{TGI}_{1}=68.4 \%$ for one-step DDS and $\mathrm{TGI}_{2}=94.9 \%$ for two-step DDS. The obtained data show that the two-step delivery of the same dose of doxorubicin-loaded nanoparticles is much more effective than one-step both in terms of diagnostics and therapy. 


\section{Discussion}

Polymer nanoparticles are the most promising vectors for targeted drug delivery due to their high biocompatibility, a wide spectrum of materials available for synthesis, and the ease of modification with molecules of different origins and functionality [45]. Among the wide range of natural and synthetic polymer materials for the design of therapeutic nanoparticles (such as protein-based polymers, polyphosphates, polyamides, polysaccharides, poly-lactic-co-glycolic acid) PLGA is the most popular polymer commonly used for biomedical and fundamental research applications [36, 46]. PLGA has already been approved by the FDA for therapeutic purposes and acts as a unique polymer for drug delivery $[47,48]$. PLGA is a co-polymer of fully biocompatible and biodegradable lactic and glycolic acids and has already demonstrated remarkable results in clinical trials as an excellent candidate for drug delivery and treatment $[49,50]$.

To track the nanoparticles inside the organism, monitor their delivery and biodistribution, and use them for diagnostic tasks, we incorporated the fluorescent dye, namely, Nile Blue, into the nanoparticle structure. Nile Blue is a fluorescent dye from the benzophenoxazine family with high fluorescence, high quantum yield, and excellent photostability [51]. The maximum excitation of the dye in dimethyl sulfoxide is 636 $\mathrm{nm}$, and the maximum emission is $669 \mathrm{~nm}$, thus entering the transparency window of biological tissues and making this dye promising for imaging applications in vivo [51]. Due to its lipophilic structure, Nile Blue was already used for several biological applications, e.g., for histology in vitro. Moreover, several in vivo studies have demonstrated the ability of this dye to accumulate in tumor cells after i.v. administration $[42,52]$. Despite the above-mentioned advantages and low cost, Nile Blue was unjustly underestimated in biology with a limited number of studies related to its usage.

Here we describe the development of the two-step drug delivery system based on polymer PLGA nanoparticles possessing both diagnostic and therapeutic properties. The delivery of these nanoparticles to HER2-overexpressing cancer cells is realized via proteinaceous barnase*barstar interface and HER2recognizing scaffold protein DARPin9_29. The concept of targeted drug delivery suggests several advantages over standard chemotherapy, such as the decrease of the required dose of a drug, the improved drug penetration into the tumor, and the reduction of side effects [10]. However, the use of traditional targeting molecules for the therapeutics delivery, namely the use of monoclonal antibodies, often leads to a wide spectrum of undesirable effects: i) considerable size of antibodies (150 kDa, 7-14 $\mathrm{nm}$ ) often does not allow to modify the nanoparticle surface with the required number of IgG molecules for the efficient delivery to cells, ii) post-translational modifications of IgGs require biotechnological production in mammals which is time-consuming and expensive, iii) constant domains of the heavy chains have effector functions that may lead to phagocytosis without participating in the selective target recognizing, or can cause unwanted immunomodulation in vivo; iv) the presence of cysteines in the antibody molecule and glycosylation, which play an important structural role [28, 53-56].

The artificial scaffold polypeptides were used in this study to target the nanoparticles toward cancer cells instead of the traditionally used monoclonal antibodies. In the last two decades, targeted polypeptide 
scaffold molecules of non-immunoglobulin nature obtained by phage, cellular or ribosomal display technologies seem to be more effective tools for the delivery of nanoparticles and other substances to the target cells in the tumor site. The most promising synthetic scaffold proteins for the targeted delivery are DARPins (synthetic derivatives of cytoskeleton protein of drosophila - ankyrin) [30, 57-60], monobodies (derivatives of human fibronectin FN3 domain) [61], anticalins (derivatives of lipocalins) [62], avimers (derivatives of extracellular receptor A-domain) [55], affibodies (derivatives of highly stable domain B of staphylococcal protein A) [46] and others. Designed ankyrin repeat protein, or DARPin, was used in this study for the following reasons: it has a small size $(14 \mathrm{kDa})$, high affinity to the molecular target, namely receptor HER2 $\left(\mathrm{K}_{\mathrm{D}}=3.8 \mathrm{nM}\right)$, low immunogenicity, exceptional thermodynamic stability, and absence of cysteines in its structure $[30,63,64]$.

Equally important is the ease of large-scale biotechnological production, in contrast to full-size antibodies $[30,65]$. All these properties simplify genetic engineering and the creation of multispecific fusion proteins, which allow not only targeting different structures to the cells with specific molecular profiles but also realizing their own diagnostic and therapeutic functions $[36,40,57,60,66]$. Here we used DARPin9_29 genetically fused with barstar, which showed highly specific binding to receptor HER2 and allowed us to realize the two-step delivery system based on barnase*barstar interface.

Several two-step DDSs are currently in use and under development (see Table 1). As shown in Table 1, barnase*barstar protein pair outperforms other two-step systems which makes it a unique tool for the design of multifunctional biomedical products. Barstar $(10 \mathrm{kDa})$ is a natural inhibitor of bacterial ribonuclease barnase (12 kDa) [38]. These proteins have an extremely high binding affinity (association constant $\mathrm{K}_{\mathrm{aff}} \sim 10^{14} \mathrm{M}^{-1}$ ) and fast interaction kinetics (rate constant of complex formation $\mathrm{k}_{\mathrm{on}} \sim 10^{8} \mathrm{M}^{-}$ $\left.{ }^{1} \mathrm{~s}^{-1}\right)$, at the same time, these proteins are not presented in mammals, which allows them to be used in blood flow without any interaction with endogenic components of blood $[67,68]$. In the present study, barstar-DARPin9_29 was used as the first component of the two-step DDS and nanoparticles modified with barnase served as the second component. It is also important to note the lack of immunogenicity of this protein pair, which was shown above.

Previously we showed the versatility of the barnase*barstar protein system for a wide range of applications, including targeted delivery of protein molecules, nanoparticles, and different supramolecular structures. In particular: i) the stability of the barnase*barstar protein complex under severe conditions (low pH, high temperature, and presence of chaotropic agents) was demonstrated that opens up more possibilities for using this system in any conditions both in vitro and in vivo [69]; ii) the successful labeling of HER2-overexpressing cancer cells in vitro with the self-assembled structures consisting of the magnetic particles and quantum dots using barstar and scFv-barnase-scFv construct (directed toward HER2 antigen) [35] and in vivo with radiolabeled 4D5 scFv-barnase and 4D5 scFv-dibarnase [38] were shown; iii) a universal delivery system based on barnase*barstar and $\mathrm{SiO}_{2}$-binding peptide was developed [40]; iv) bispecific antibodies against HER1 and HER2 antigens using 425scFv-barstar and 4D5scFvbarnase [70] were obtained and utilized for imaging of cancer cells with overexpression of these receptors 
[71]. All the described studies confirm the versatility of the barnase*barstar interface for the wide range of biological applications that require the self-assembly of different structures in different conditions. 
Table 1

The interfaces used for the drug delivery systems with pre-targeting step.

\begin{tabular}{|c|c|c|c|c|}
\hline Delivery system & Immunogenicity & $\begin{array}{l}\text { Sterical } \\
\text { hindrance }\end{array}$ & $\mathrm{Ka}$ & $\begin{array}{l}\text { Representation in } \\
\text { mammals }\end{array}$ \\
\hline $\begin{array}{l}\text { Barnase* } \\
\text { barstar }\end{array}$ & $\begin{array}{l}\checkmark \text { Both proteins are } \\
\text { not immunogenic } \\
\text { (this study). }\end{array}$ & $\begin{array}{l}\checkmark \text { Proteins are } \\
\text { comparable } \\
\text { in size }(12 \\
\text { and } 10 \mathrm{kDa}), \\
\text { and therefore } \\
\text { steric } \\
\text { hindrances } \\
\text { should not } \\
\text { arise [38]. }\end{array}$ & $\begin{array}{l}10^{14} \mathrm{M}^{-1} \\
{[68]}\end{array}$ & $\begin{array}{l}\checkmark \text { Both proteins were } \\
\text { isolated from } \\
\text { bacteria and are not } \\
\text { represented in } \\
\text { mammals [68]. }\end{array}$ \\
\hline Streptavidin*biotin & $\begin{array}{l}\text { घStreptavidin is } \\
\text { highly immunogenic } \\
\text { [72]. }\end{array}$ & $\begin{array}{l}\otimes T h e \\
\text { significant } \\
\text { difference in } \\
\text { the size }(56 \\
\mathrm{kDa} \text { and } 244 \\
\text { Da) of the } \\
\text { molecules } \\
\text { can cause } \\
\text { steric } \\
\text { hindrance: if } \\
\text { biotin is } \\
\text { bound to a } \\
\text { non-smooth } \\
\text { surface, then } \\
\text { streptavidin } \\
\text { will not be } \\
\text { able to } \\
\text { recognize it. } \\
\text { This imposes } \\
\text { restrictions on } \\
\text { the use of this } \\
\text { system in } \\
\text { nanomedicine } \\
\text { [73-75]. }\end{array}$ & $\begin{array}{l}10^{15} \mathrm{M}^{-1} \\
{[76]}\end{array}$ & $\begin{array}{l}\text { QBiotin, or vitamin } \mathrm{H} \text {, } \\
\text { is presented in the } \\
\text { blood of mammals } \\
\text { which may cause } \\
\text { obstacles for } \\
\text { appropriate } \\
\text { interaction of } \\
\text { streptavidin*biotin } \\
\text { [77-79]. }\end{array}$ \\
\hline $\begin{array}{l}\text { Hapten* } \\
\text { antibody }\end{array}$ & $\begin{array}{l}\text { \Antibodies are } \\
\text { immunogenic and } \\
\text { may have effector } \\
\text { functions which } \\
\text { make them not the } \\
\text { best candidate for } \\
\text { long-term treatment } \\
\text { [80]. }\end{array}$ & $\begin{array}{l}\text { \lgG is } 150 \\
\text { kDa protein, } \\
\text { while hapten } \\
\text { is a low- } \\
\text { molecular } \\
\text { compound, so } \\
\text { steric } \\
\text { difficulties } \\
\text { may arise } \\
\text { when the } \\
\text { components } \\
\text { interact [80, } \\
\text { 81]. }\end{array}$ & $\begin{array}{l}10^{5}-10^{10} \\
\mathrm{M}^{-1}[82]\end{array}$ & $\begin{array}{l}\text { \Antibodies are } \\
\text { presented in blood } \\
\text { and have effector } \\
\text { functions as critical } \\
\text { participants in the } \\
\text { immune defense } \\
\text { [28]. }\end{array}$ \\
\hline
\end{tabular}




\begin{tabular}{|c|c|c|c|c|}
\hline Delivery system & Immunogenicity & $\begin{array}{l}\text { Sterical } \\
\text { hindrance }\end{array}$ & $\mathrm{Ka}$ & $\begin{array}{l}\text { Representation in } \\
\text { mammals }\end{array}$ \\
\hline $\begin{array}{l}\text { Nucleic acids: } \\
\text { i) DNA*DNA } \\
\text { ii) RNA*RNA } \\
\text { iii) mirror-imaged } \\
\text { oligonucleotides } \\
\text { iv) } \\
\text { phosphorodiamidate } \\
\text { morpholino } \\
\text { oligomers } \\
\text { v) peptide nucleic } \\
\text { acids } \\
\text { vi) locked nucleic } \\
\text { acid }\end{array}$ & $\begin{array}{l}\checkmark \text { It was proposed } \\
\text { that nucleotides as } \\
\text { natural, presented in } \\
\text { all organisms } \\
\text { molecules with a } \\
\text { high charge will be } \\
\text { not immunogenic } \\
\text { [83]. } \\
\checkmark \text { It was shown that } \\
\text { some mirror-imaged } \\
\text { oligonucleotides, as } \\
\text { well as } \\
\text { phosphorodiamidate } \\
\text { morpholino } \\
\text { oligomers and } \\
\text { peptide nucleic } \\
\text { acids, are not } \\
\text { immunogenic [84- } \\
\text { 87]. }\end{array}$ & $\begin{array}{l}\text { \Nucleotides } \\
\text { are small } \\
\text { molecules } \\
\text { (less than } 500 \\
\text { Da). Since the } \\
\text { entire } \\
\text { sequence of } \\
\text { nucleotides is } \\
\text { vital in } \\
\text { recognition, it } \\
\text { can cause } \\
\text { interaction } \\
\text { problems if a } \\
\text { non-smooth } \\
\text { surface is } \\
\text { used. }\end{array}$ & $\begin{array}{l}\text { Depending } \\
\text { on the base } \\
\text { pair } \\
\text { number }\end{array}$ & $\begin{array}{l}\text { QThe presence of } \\
\text { nucleases in the } \\
\text { serum is an obstacle } \\
\text { in the development } \\
\text { of the system based } \\
\text { on oligonucleotides } \\
\text { due to the fast } \\
\text { degradation [83]. } \\
\text { } \text { Due to their } \\
\text { artificial origin } \\
\text { mirror-imaged } \\
\text { oligonucleotides, } \\
\text { phosphorodiamidate } \\
\text { morpholino } \\
\text { oligomers and } \\
\text { peptide nucleic } \\
\text { acids are resistant to } \\
\text { the degradation by } \\
\text { the nucleases, } \\
\text { peptide and locked } \\
\text { nucleic acids are } \\
\text { also resistant to } \\
\text { protease digestion } \\
85,87-90] \text {. }\end{array}$ \\
\hline Click chemistry & $\begin{array}{l}\checkmark \text { Molecules used in } \\
\text { bioorthogonal } \\
\text { chemistry are } \\
\text { supposed to be not } \\
\text { highly immunogenic } \\
\text { [91]. }\end{array}$ & $\begin{array}{l}\text { QMolecules } \\
\text { used in } \\
\text { bioorthogonal } \\
\text { chemistry are } \\
\text { small, which } \\
\text { can cause } \\
\text { interaction } \\
\text { problems if a } \\
\text { non-smooth } \\
\text { surface is } \\
\text { used. Also, } \\
\text { this approach } \\
\text { requires } \\
\text { preliminary } \\
\text { chemical } \\
\text { modification } \\
\text { of the } \\
\text { delivered } \\
\text { molecules, } \\
\text { which } \\
\text { proceed not } \\
\text { completely } \\
\text { steric and not } \\
\text { with } 100 \% \\
\text { yield. }\end{array}$ & $\begin{array}{l}\checkmark \mathbb{} \text { Covalent } \\
\text { bonding is } \\
\text { stronger } \\
\text { than } \\
\text { affinity } \\
\text { interaction } \\
\text { but is not } \\
\text { reversible. }\end{array}$ & $\begin{array}{l}\checkmark \text { Molecules used in } \\
\text { bioorthogonal } \\
\text { chemistry are not } \\
\text { represented in } \\
\text { mammals [88]. }\end{array}$ \\
\hline
\end{tabular}




\begin{tabular}{|c|c|c|c|c|}
\hline Delivery system & Immunogenicity & $\begin{array}{l}\text { Sterical } \\
\text { hindrance }\end{array}$ & $\mathrm{Ka}$ & $\begin{array}{l}\text { Representation in } \\
\text { mammals }\end{array}$ \\
\hline $\begin{array}{l}\text { SpyTag/ } \\
\text { SpyCatcher }\end{array}$ & N/A & $\begin{array}{l}\checkmark \text { Proteins are } \\
\text { comparable } \\
\text { in size }(15 \\
\text { and } 13 \mathrm{kDa}), \\
\text { and therefore } \\
\text { steric } \\
\text { hindrances } \\
\text { should not } \\
\text { arise[92]. }\end{array}$ & $\begin{array}{l}\checkmark \square \\
\text { Covalent } \\
\text { bonding is } \\
\text { stronger } \\
\text { than } \\
\text { affinity } \\
\text { interaction } \\
\text { but is not } \\
\text { reversible. }\end{array}$ & $\begin{array}{l}\text { Both proteins were } \\
\text { isolated from } \\
\text { bacteria and } \\
\text { modified by } \\
\text { bioengineering and } \\
\text { are not represented } \\
\text { in mammals [93]. }\end{array}$ \\
\hline
\end{tabular}

In this work, using barstar-DARPin9_29 and barnase-conjugated polymer PLGA nanoparticles loaded with fluorescent dye, Nile Blue, and chemotherapeutic drug, doxorubicin, we showed successful labeling and killing of HER2-overexpressing cells in vitro. Namely, we showed that IC50 of doxorubicin delivered via two-step DDS is more than 100 times lower than that for one-step DDS: IC50 $=43 \pm 3 \mathrm{nM}$ for two-step DDS vs. IC50 = $4972 \pm 1965 \mathrm{nM}$ for one-step DDS. Moreover, the developed two-step DDS based on barnase*barstar showed superior efficiency in image-guided cancer therapy: HER2-positive tumors' treatment tests showed the tumor growth inhibition index TGI $=68.4 \%$ for one-step DDS and TGI $=94.9 \%$ for two-step DDS. The obtained results demonstrate the significant superority of two-step drug delivery over the classical one-step one. We expect these data to change the paradigm in next-generation drug development and force researchers to focus on multi-step targeted drug delivery to reduce the required dose in cancer therapy.

\section{Conclusions}

Here we report the versatile method of the two-step drug delivery system (DDS) for theranostic applications based on barnase*barstar proteinaceous interface. The small size and high affinity constant of these proteins make them an excellent "molecular glue" for the design of different self-assembling structures based on various modules, where one component of this DDS is in the structure of one module (e.g., barnase in the therapeutic module), and another system component in the structure of another module (e.g., barstar in targeted anti-HER2 DARPin module). This "lego" approach allows escaping such chemical conjugation issues, as non-oriented molecule modification of nanoparticle surface, denaturation of proteins on the nanoparticle surface, conjugation through several functional groups on the same molecule, impossibility of simple replacement of nanoparticle composition. On the contrary, using the proposed platform for nanoparticle biomodification allows obtaining biologically active structures by either mixing components, such as nanoparticle-barnase + barstar-DARPin or two-step targeted delivery in vitro and in vivo. Such a pre-targeting concept allows to significantly reduce the doses of drugs and increase the efficacy of image-guided cancer treatment. We believe that the proposed system outperforming the existing technologies will promote the development of new-generation drug delivery systems for cancer diagnostics and treatment.

\section{Declarations}




\section{Funding}

Not applicable.

\section{Acknowledgments}

Not applicable.

\section{Author Contributions}

Conceptualization: V.O.S., M.P.N., S.M.D.; data curation: V.O.S. E.N.K.; formal analysis: V.O.S.; investigation: V.O.S.; methodology: V.O.S., A.V.S., M.P.N.; project administration: V.O.S.; resources: V.O.S., M.P.N., S.M.D.; software: A.S.S.; supervision: V.O.S.; validation: V.O.S. E.N.K. P.A.K.; visualization: A.S.S., E.D.T., M.M.B.; writing - original draft: V.O.S., E.N.K., M.P.N. S.M.D.

\section{Ethics approval and consent to participate}

Not applicable.

\section{Consent for publication}

All authors read and approve the final manuscript.

\section{Availability of data and materials}

The datasets used and analyzed during the current study are available from the corresponding author on reasonable request.

\section{Competing interests}

Maxim P. Nikitin is the founder of Abisense company.

\section{References}

1. Sung H, Ferlay J, Siegel RL, Laversanne M, Soerjomataram I, Jemal A, Bray F. Global cancer statistics 2020: GLOBOCAN estimates of incidence and mortality worldwide for 36 cancers in 185 countries. CA Cancer J Clin 2021. doi:10.3322/caac.21660.

2. Carrick S, Parker S, Thornton CE, Ghersi D, Simes J, Wilcken N. Single agent versus combination chemotherapy for metastatic breast cancer. Cochrane Database Syst Rev. 2009:CD 003372. doi:10.1002/14651858.CD003372.pub3.

3. Sweeney CJ, Chen Y-H, Carducci M, Liu G, Jarrard DF, Eisenberger M, et al. Chemohormonal Therapy in Metastatic Hormone-Sensitive Prostate Cancer. N Engl J Med. 2015;373:737-46. doi:10.1056/nejmoa1503747. 
4. Chen Z, Li H, Bian Y, Wang Z, Chen G, Zhang X, et al. Bioorthogonal catalytic patch. Nat Nanotechnol. 2021;16:933-41. doi:10.1038/s41565-021-00910-7.

5. Liang T, Chen Z, Li H, Gu Z. Bioorthogonal catalysis for biomedical applications. Trends in Chemistry. 2021;69:290. doi:10.1016/j.trechm.2021.11.008.

6. Artykov AA, Belov DA, Shipunova VO, Trushina DB, Deyev SM, Dolgikh DA, et al. Chemotherapeutic Agents Sensitize Resistant Cancer Cells to the DR5-Specific Variant DR5-B more Efficiently than to TRAIL by Modulating the Surface Expression of Death and Decoy Receptors. Cancers (Basel) 2020. doi:10.3390/CANCERS12051129.

7. Ukrainskaya V, Rubtsov Y, Pershin D, Podoplelova N, Terekhov S, Yaroshevich I, et al. Antigen-Specific Stimulation and Expansion of CAR-T Cells Using Membrane Vesicles as Target Cell Surrogates. Small. 2021;17:e2102643. doi:10.1002/SMLL.202102643.

8. Li H, Wang Z, Chen Z, Ci T, Chen G, Di Wen, et al. Disrupting tumour vasculature and recruitment of aPDL1-loaded platelets control tumour metastasis. Nat Commun. 2021;12:2773. doi:10.1038/s41467-021-22674-3.

9. Belova MM, Shipunova VO, Kotelnikova PA, Babenyshev AV, Rogozhin EA, Cherednichenko MY, Deyev SM. "Green" Synthesis of Cytotoxic Silver Nanoparticles Based on Secondary Metabolites of Lavandula Angustifolia Mill. Acta Naturae. 2019;11:47-53. doi:10.32607/20758251-2019-11-2-47-53.

10. Anselmo AC, Mitragotri S. Nanoparticles in the clinic. Bioeng Transl Med. 2016;1:10-29. doi:10.1002/btm2.10003.

11. Wang AZ, Langer R, Farokhzad OC. Nanoparticle delivery of cancer drugs. Annu Rev Med. 2012;63:185-98. doi:10.1146/annurev-med-040210-162544.

12. Zelepukin IV, Yaremenko AV, Shipunova VO, Babenyshev AV, Balalaeva IV, Nikitin PI, et al. Nanoparticle-based drug delivery via RBC-hitchhiking for the inhibition of lung metastases growth. Nanoscale. 2019;11:1636-46. doi:10.1039/C8NR07730D.

13. Nikitin MP, Zelepukin IV, Shipunova VO, Sokolov IL, Deyev SM, Nikitin PI. Enhancement of the bloodcirculation time and performance of nanomedicines via the forced clearance of erythrocytes. Nat Biomed Eng. 2020;4:717-31. doi:10.1038/s41551-020-0581-2.

14. Nikitin MP, Shipunova VO, Deyev SM, Nikitin PI. Biocomputing based on particle disassembly. Nat Nanotechnol. 2014;9:716-22. doi:10.1038/nnano.2014.156.

15. Shipunova VO, Kovalenko VL, Kotelnikova PA, Sogomonyan AS, Shilova ON, Komedchikova EN, et al. Targeting Cancer Cell Tight Junctions Enhances PLGA-Based Photothermal Sensitizers' Performance In Vitro and In Vivo. Pharmaceutics. 2022;14:43. doi:10.3390/PHARMACEUTICS14010043.

16. Yashchenok AM, Gusliakova OI, Konovalova EV, Novoselova MV, Shipunova VO, Abakumova TO, et al. Barnase encapsulation into submicron porous $\mathrm{CaCO} 3$ particles: studies of loading and enzyme activity. J Mater Chem B. 2021;9:8823-31. doi:10.1039/D1TB01315G.

17. Rivankar S. An overview of doxorubicin formulations in cancer therapy. J Cancer Res Ther. 2014;10:853-8. doi:10.4103/0973-1482.139267. 
18. Krauss AC, Gao X, Li L, Manning ML, Patel P, Fu W, et al. FDA Approval Summary: (Daunorubicin and Cytarabine) Liposome for Injection for the Treatment of Adults with High-Risk Acute Myeloid Leukemia. Clin Cancer Res. 2019;25:2685-90. doi:10.1158/1078-0432.CCR-18-2990.

19. Riley RS, June CH, Langer R, Mitchell MJ. Delivery technologies for cancer immunotherapy. Nat Rev Drug Discov. 2019;18:175-96. doi:10.1038/s41573-018-0006-z.

20. Shipunova VO, Nikitin MP, Belova MM, Deyev SM. Label-free methods of multiparametric surface plasmon resonance and MPQ-cytometry for quantitative real-time measurements of targeted magnetic nanoparticles complexation with living cancer cells. Materials Today Communications. 2021;29:102978. doi:10.1016/J.MTCOMM.2021.102978.

21. Zelepukin IV, Popov AA, Shipunova VO, Tikhonowski GV, Mirkasymov AB, Popova-Kuznetsova EA, et al. Laser-synthesized TiN nanoparticles for biomedical applications: Evaluation of safety, biodistribution and pharmacokinetics. Mater Sci Eng C Mater Biol Appl. 2021;120:111717. doi:10.1016/J.MSEC.2020.111717.

22. Zelepukin IV, Mashkovich EA, Lipey NA, Popov AA, Shipunova VO, Yu. Griaznova O, et al. Direct photoacoustic measurement of silicon nanoparticle degradation promoted by a polymer coating. Chemical Engineering Journal. 2022;430:132860. doi:10.1016/j.cej.2021.132860.

23. Shipunova VO, Nikitin MP, Nikitin PI, Deyev SM. MPQ-cytometry: a magnetism-based method for quantification of nanoparticle-cell interactions. Nanoscale. 2016;8:12764-72. doi:10.1039/C6NR03507H.

24. Kabashin AV, Kravets VG, Wu F, Imaizumi S, Shipunova VO, Deyev SM, Grigorenko AN. PhaseResponsive Fourier Nanotransducers for Probing 2D Materials and Functional Interfaces. Adv. Funct. Mater. 2019;29:1902692. doi:10.1002/ADFM.201902692.

25. Proshkina GM, Shramova El, Shilova MV, Zelepukin IV, Shipunova VO, Ryabova AV, et al. DARPin_9-29Targeted Gold Nanorods Selectively Suppress HER2-Positive Tumor Growth in Mice. Cancers (Basel) 2021. doi:10.3390/CANCERS13205235.

26. Senzer N, Nemunaitis J, Nemunaitis D, Bedell C, Edelman G, Barve M, et al. Phase I study of a systemically delivered p53 nanoparticle in advanced solid tumors. Mol Ther. 2013;21:1096-103. doi:10.1038/mt.2013.32.

27. Hoff DD von, Mita MM, Ramanathan RK, Weiss GJ, Mita AC, LoRusso PM, et al. Phase I Study of PSMA-Targeted Docetaxel-Containing Nanoparticle BIND-014 in Patients with Advanced Solid Tumors. Clin Cancer Res. 2016;22:3157-63. doi:10.1158/1078-0432.CCR-15-2548.

28. Rosenblum D, Joshi N, Tao W, Karp JM, Peer D. Progress and challenges towards targeted delivery of cancer therapeutics. Nat Commun. 2018;9:1410. doi:10.1038/s41467-018-03705-y.

29. Skerra A. Engineered protein scaffolds for molecular recognition. J. Mol. Recognit. 2000;13:167-87. doi:10.1002/1099-1352(200007/08)13:4<167::aid-jmr502>3.0.co;2-9.

30. Binz HK, Amstutz P, Plückthun A. Engineering novel binding proteins from nonimmunoglobulin domains. Nat Biotechnol. 2005;23:1257-68. doi:10.1038/nbt1127. 
31. Ståhl S, Gräslund T, Eriksson Karlström A, Frejd FY, Nygren P-Å, Löfblom J. Affibody Molecules in Biotechnological and Medical Applications. Trends in Biotechnology. 2017;35:691-712. doi:10.1016/j.tibtech.2017.04.007.

32. Su X, Yang N, Wittrup KD, Irvine DJ. Synergistic antitumor activity from two-stage delivery of targeted toxins and endosome-disrupting nanoparticles. Biomacromolecules. 2013;14:1093-102. doi:10.1021/bm3019906.

33. Sharkey RM, Karacay H, Cardillo TM, Chang C-H, McBride WJ, Rossi EA, et al. Improving the delivery of radionuclides for imaging and therapy of cancer using pretargeting methods. Clin Cancer Res. 2005;11:7109s-7121s. doi:10.1158/1078-0432.CCR-1004-0009.

34. Marshall D, Pedley RB, Boden JA, Boden R, Melton RG, Begent RH. Polyethylene glycol modification of a galactosylated streptavidin clearing agent: effects on immunogenicity and clearance of a biotinylated anti-tumour antibody. Br J Cancer. 1996;73:565-72. doi:10.1038/bjc.1996.99.

35. Nikitin MP, Zdobnova TA, Lukash SV, Stremovskiy OA, Deyev SM. Protein-assisted self-assembly of multifunctional nanoparticles. Proc Natl Acad Sci U S A. 2010;107:5827-32. doi:10.1073/pnas.1001142107.

36. Shipunova VO, Komedchikova EN, Kotelnikova PA, Zelepukin IV, Schulga AA, Proshkina GM, et al. Dual Regioselective Targeting the Same Receptor in Nanoparticle-Mediated Combination Immuno/Chemotherapy for Enhanced Image-Guided Cancer Treatment. ACS Nano. 2020;14:1278195. doi:10.1021/acsnano.0c03421.

37. Crocker JC, Grier DG. Methods of Digital Video Microscopy for Colloidal Studies. Journal of Colloid and Interface Science. 1996;179:298-310. doi:10.1006/jcis.1996.0217.

38. Deyev SM, Waibel R, Lebedenko EN, Schubiger AP, Plückthun A. Design of multivalent complexes using the barnase*barstar module. Nat Biotechnol. 2003;21:1486-92. doi:10.1038/nbt916.

39. Rushizky GW, Greco AE, Hartley RW, Sober HA. STUDIES ON B. SUBTILIS RIBONUCLEASE. I. CHARACTERIZATION OF ENZYMATIC SPECIFICITY. Biochemistry. 1963;2:787-93. doi:10.1021/bi00904a028.

40. Shipunova VO, Zelepukin IV, Stremovskiy OA, Nikitin MP, Care A, Sunna A, et al. Versatile Platform for Nanoparticle Surface Bioengineering Based on SiO2-Binding Peptide and Proteinaceous Barnase*Barstar Interface. ACS Appl Mater Interfaces. 2018;10:17437-47. doi:10.1021/acsami.8b01627.

41. Studier FW. Protein production by auto-induction in high density shaking cultures. Protein Expr Purif. 2005;41:207-34. doi:10.1016/j.pep.2005.01.016.

42. Lin CW, Shulok JR, Kirley SD, Cincotta L, Foley JW. Lysosomal localization and mechanism of uptake of Nile blue photosensitizers in tumor cells. Cancer Res. 1991;51:2710-9.

43. Nitiss JL. Targeting DNA topoisomerase II in cancer chemotherapy. Nat Rev Cancer. 2009;9:338-50. doi:10.1038/nrc2607.

44. Thorn CF, Oshiro C, Marsh S, Hernandez-Boussard T, McLeod H, Klein TE, Altman RB. Doxorubicin pathways: pharmacodynamics and adverse effects. Pharmacogenet Genomics. 2011;21:440-6. 
doi:10.1097/FPC.0b013e32833ffb56.

45. Masood F. Polymeric nanoparticles for targeted drug delivery system for cancer therapy. Mater Sci Eng C Mater Biol Appl. 2016;60:569-78. doi:10.1016/j.msec.2015.11.067.

46. Shipunova VO, Sogomonyan AS, Zelepukin IV, Nikitin MP, Deyev SM. PLGA Nanoparticles Decorated with Anti-HER2 Affibody for Targeted Delivery and Photoinduced Cell Death. Molecules 2021. doi:10.3390/molecules26133955.

47. Pillai O, Panchagnula R. Polymers in drug delivery. Curr Opin Chem Biol. 2001;5:447-51. doi:10.1016/s1367-5931(00)00227-1.

48. Danhier F, Ansorena E, Silva JM, Coco R, Le Breton A, Préat V. PLGA-based nanoparticles: an overview of biomedical applications. J Control Release. 2012;161:505-22. doi:10.1016/j.jconrel.2012.01.043.

49. El-Maghawry E, Tadros MI, Elkheshen SA, Abd-Elbary A. Eudragit@-S100 Coated PLGA Nanoparticles for Colon Targeting of Etoricoxib: Optimization and Pharmacokinetic Assessments in Healthy Human Volunteers. Int J Nanomedicine. 2020;15:3965-80. doi:10.2147/IJN.S244124.

50. Lecio G, Ribeiro FV, Pimentel SP, Reis AA, Da Silva RVC, Nociti-Jr F, et al. Novel 20\% doxycyclineloaded PLGA nanospheres as adjunctive therapy in chronic periodontitis in type-2 diabetics: randomized clinical, immune and microbiological trial. Clin Oral Investig. 2020;24:1269-79. doi:10.1007/s00784-019-03005-9.

51. Martinez V, Henary M. Nile Red and Nile Blue: Applications and Syntheses of Structural Analogues. Chemistry. 2016;22:13764-82. doi:10.1002/chem.201601570.

52. LEWIS MR, GOLAND PP, SLOVITER HA. The action of oxazine dyes on tumors in mice. Cancer Res. 1949;9:736-40.

53. Shipunova VO, Deyev SM. Artificial scaffold polypeptides as an efficient tool for the targeted delivery of nanostructures in vitro and in vivo. Acta Naturae. 2022;14.

54. Gebauer M, Skerra A. Engineered protein scaffolds as next-generation antibody therapeutics. Curr Opin Chem Biol. 2009;13:245-55. doi:10.1016/j.cbpa.2009.04.627.

55. Silverman J, Liu Q, Lu Q, Bakker A, To W, Duguay A, et al. Multivalent avimer proteins evolved by exon shuffling of a family of human receptor domains. Nat Biotechnol. 2005;23:1556-61. doi:10.1038/nbt1166.

56. Parizek P, Kummer L, Rube P, Prinz A, Herberg FW, Plückthun A. Designed ankyrin repeat proteins (DARPins) as novel isoform-specific intracellular inhibitors of c-Jun $\mathrm{N}$-terminal kinases. ACS Chem Biol. 2012;7:1356-66. doi:10.1021/cb3001167.

57. Shipunova VO, Shramova El, Schulga AA, Shilova MV, Deyev SM, Proshkina GM. Delivery of Barnase to Cells in Liposomes Functionalized by Her2-Specific DARPin Module. Russ J Bioorg Chem. 2020;46:1156-61. doi:10.1134/S1068162020060308.

58. Shipunova VO, Kolesnikova OA, Kotelnikova PA, Soloviev VD, Popov AA, Proshkina GM, et al. Comparative Evaluation of Engineered Polypeptide Scaffolds in HER2-Targeting Magnetic Nanocarrier Delivery. ACS Omega. 2021;6:16000-8. doi:10.1021/acsomega.1c01811. 
59. Shipunova VO, Kotelnikova PA, Aghayeva UF, Stremovskiy OA, Novikov IA, Schulga AA, et al. Selfassembling nanoparticles biofunctionalized with magnetite-binding protein for the targeted delivery to HER2/neu overexpressing cancer cells. Journal of Magnetism and Magnetic Materials. 2019;469:450-5. doi:10.1016/j.jmmm.2018.09.015.

60. Shramova E, Proshkina G, Shipunova V, Ryabova A, Kamyshinsky R, Konevega A, et al. Dual Targeting of Cancer Cells with DARPin-Based Toxins for Overcoming Tumor Escape. Cancers (Basel) 2020. doi:10.3390/cancers12103014.

61. Koide A, Wojcik J, Gilbreth RN, Hoey RJ, Koide S. Teaching an old scaffold new tricks: monobodies constructed using alternative surfaces of the FN3 scaffold. J Mol Biol. 2012;415:393-405. doi:10.1016/j.jmb.2011.12.019.

62. Beste G, Schmidt FS, Stibora T, Skerra A. Small antibody-like proteins with prescribed ligand specificities derived from the lipocalin fold. Proc Natl Acad Sci U S A. 1999;96:1898-903. doi:10.1073/pnas.96.5.1898.

63. Steiner $D$, Forrer $P$, Plückthun $A$. Efficient selection of DARPins with sub-nanomolar affinities using SRP phage display. J Mol Biol. 2008;382:1211-27. doi:10.1016/j.jmb.2008.07.085.

64. Deyev S, Vorobyeva A, Schulga A, Proshkina G, Güler R, Löfblom J, et al. Comparative Evaluation of Two DARPin Variants: Effect of Affinity, Size, and Label on Tumor Targeting Properties. Mol Pharm. 2019;16:995-1008. doi:10.1021/acs.molpharmaceut.8b00922.

65. Frejd FY, Kim K-T. Affibody molecules as engineered protein drugs. Exp Mol Med. 2017;49:e306. doi:10.1038/emm.2017.35.

66. Kotelnikova PA, Shipunova VO, Aghayeva UF, Stremovskiy OA, Nikitin MP, Novikov IA, et al. Synthesis of Magnetic Nanoparticles Stabilized by Magnetite-Binding Protein for Targeted Delivery to Cancer Cells. Dokl Biochem Biophys. 2018;481:198-200. doi:10.1134/S1607672918040051.

67. Schreiber G, Fersht AR. Energetics of protein-protein interactions: Analysis ofthe Barnase-Barstar interface by single mutations and double mutant cycles. J Mol Biol. 1995;248:478-86. doi:10.1016/s0022-2836(95)80064-6.

68. Schreiber G. Methods for studying the interaction of barnase with its inhibitor barstar. Methods Mol Biol. 2001;160:213-26. doi:10.1385/1-59259-233-3:213.

69. Aghayeva UF, Nikitin MP, Lukash SV, Deyev SM. Denaturation-resistant bifunctional colloidal superstructures assembled via the proteinaceous barnase-barstar interface. ACS Nano. 2013;7:95061. doi:10.1021/nn302546v.

70. Semenyuk EG, Stremovskiy OA, Edelweiss EF, Shirshikova OV, Balandin TG, Buryanov YI, Deyev SM. Expression of single-chain antibody-barstar fusion in plants. Biochimie. 2007;89:31-8. doi:10.1016/j.biochi.2006.07.012.

71. Zdobnova TA, Stremovskiy OA, Lebedenko EN, Deyev SM. Self-assembling complexes of quantum dots and scFv antibodies for cancer cell targeting and imaging. PLoS One. 2012;7:e48248. doi:10.1371/journal.pone.0048248. 
72. Förster GJ, Santos EB, Smith-Jones PM, Zanzonico P, Larson SM. Pretargeted radioimmunotherapy with a single-chain antibody/streptavidin construct and radiolabeled DOTA-biotin: strategies for reduction of the renal dose. J Nucl Med. 2006;47:140-9.

73. Dundas CM, Demonte D, Park S. Streptavidin-biotin technology: improvements and innovations in chemical and biological applications. Appl Microbiol Biotechnol. 2013;97:9343-53. doi:10.1007/s00253-013-5232-z.

74. Huang SC, Stump MD, Weiss R, Caldwell KD. Binding of biotinylated DNA to streptavidin-coated polystyrene latex: effects of chain length and particle size. Anal Biochem. 1996;237:115-22. doi:10.1006/abio.1996.0208.

75. Neish CS, Martin IL, Henderson RM, Edwardson JM. Direct visualization of ligand-protein interactions using atomic force microscopy. Br J Pharmacol. 2002;135:1943-50. doi:10.1038/sj.bjp.0704660.

76. Wilchek M, Bayer EA. [2] Introduction to avidin-biotin technology. In: Avidin-Biotin Technology: Elsevier; 1990. p. 5-13. doi:10.1016/0076-6879(90)84256-g.

77. Rusckowski M, Fogarasi M, Fritz B, Hnatowich DJ. Effect of endogenous biotin on the applications of streptavidin and biotin in mice. Nuclear Medicine and Biology. 1997;24:263-8. doi:10.1016/s09698051(97)00061-9.

78. Luong JHT, Male KB, Glennon JD. Biotin interference in immunoassays based on biotin-strept(avidin) chemistry: An emerging threat. Biotechnol Adv. 2019;37:634-41. doi:10.1016/j.biotechadv.2019.03.007.

79. Chen M-H, Soda Y, Izawa K, Kobayashi S, Tani K, Maruyama K, et al. A versatile drug delivery system using streptavidin-tagged pegylated liposomes and biotinylated biomaterials. Int J Pharm. 2013;454:478-85. doi:10.1016/j.ijpharm.2013.06.031.

80. Goldenberg DM. Targeted therapy of cancer with radiolabeled antibodies. J Nucl Med. 2002;43:693713.

81. Stickney DR, Anderson LD, Slater JB, Ahlem CN, Kirk GA, Schweighardt SA, Frincke JM. Bifunctional antibody: a binary radiopharmaceutical delivery system for imaging colorectal carcinoma. Cancer Res. 1991;51:6650-5.

82. Stéen EJL, Edem PE, Nørregaard K, Jørgensen JT, Shalgunov V, Kjaer A, Herth MM. Pretargeting in nuclear imaging and radionuclide therapy: Improving efficacy of theranostics and nanomedicines. Biomaterials. 2018;179:209-45. doi:10.1016/j.biomaterials.2018.06.021.

83. Kuijpers WH, Bos ES, Kaspersen FM, Veeneman GH, van Boeckel CA. Specific recognition of antibodyoligonucleotide conjugates by radiolabeled antisense nucleotides: a novel approach for two-step radioimmunotherapy of cancer. Bioconjug Chem. 1993;4:94-102. doi:10.1021/bc00019a013.

84. Wlotzka B, Leva S, Eschgfäller B, Burmeister J, Kleinjung F, Kaduk C, et al. In vivo properties of an antiGnRH Spiegelmer: an example of an oligonucleotide-based therapeutic substance class. Proc Natl Acad Sci U S A. 2002;99:8898-902. doi:10.1073/pnas.132067399.

85. Young BE, Kundu N, Sczepanski JT. Mirror-Image Oligonucleotides: History and Emerging Applications. Chemistry. 2019;25:7981-90. doi:10.1002/chem.201900149. 
86. Liu G. A Revisit to the Pretargeting Concept-A Target Conversion. Front Pharmacol. 2018;9:1476. doi:10.3389/fphar.2018.01476.

87. Altai M, Membreno R, Cook B, Tolmachev V, Zeglis BM. Pretargeted Imaging and Therapy. J Nucl Med. 2017;58:1553-9. doi:10.2967/jnumed.117.189944.

88. Patra M, Zarschler K, Pietzsch H-J, Stephan H, Gasser G. New insights into the pretargeting approach to image and treat tumours. Chem Soc Rev. 2016;45:6415-31. doi:10.1039/c5cs00784d.

89. Karkare S, Bhatnagar D. Promising nucleic acid analogs and mimics: characteristic features and applications of PNA, LNA, and morpholino. Appl Microbiol Biotechnol. 2006;71:575-86. doi:10.1007/s00253-006-0434-2.

90. Mallikaratchy P, Gardner J, Nordstrøm LUR, Veomett NJ, McDevitt MR, Heaney ML, Scheinberg DA. A self-assembling short oligonucleotide duplex suitable for pretargeting. Nucleic Acid Ther. 2013;23:289-99. doi:10.1089/nat.2013.0425.

91. van de Watering FCJ, Rijpkema M, Robillard M, Oyen WJG, Boerman OC. Pretargeted imaging and radioimmunotherapy of cancer using antibodies and bioorthogonal chemistry. Front Med (Lausanne). 2014;1:44. doi:10.3389/fmed.2014.00044.

92. Bae Y, Kim GJ, Kim H, Park SG, Jung HS, Kang S. Engineering Tunable Dual Functional Protein Cage Nanoparticles Using Bacterial Superglue. Biomacromolecules. 2018;19:2896-904. doi:10.1021/acs.biomac.8b00457.

93. Zakeri B, Fierer JO, Celik E, Chittock EC, Schwarz-Linek U, Moy VT, Howarth M. Peptide tag forming a rapid covalent bond to a protein, through engineering a bacterial adhesin. Proc Natl Acad Sci U S A. 2012;109:E690-7. doi:10.1073/pnas.1115485109.

\section{Figures}

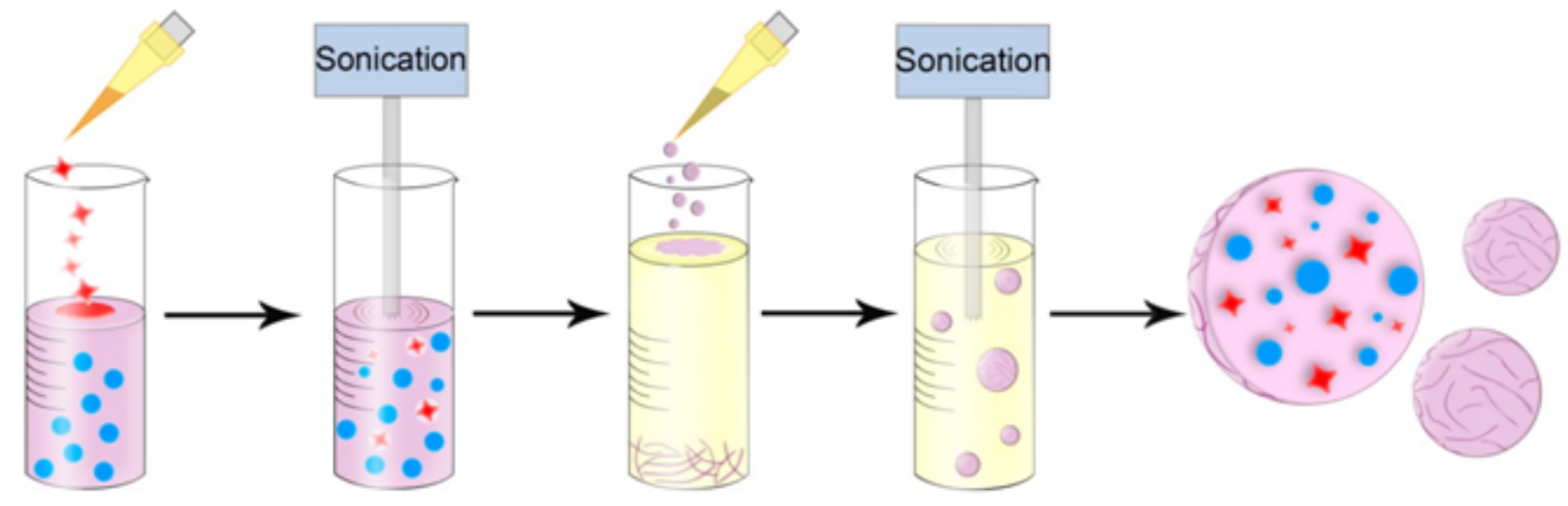

$>$ Doxorubicin

Nile Blue
PLGA Chitosan

\section{Polymer PLGA nanoparticles}

\section{Figure 1}


Schematic illustration of polymer nanoparticle synthesis by double emulsion method. The first emulsion was produced by sonication of doxorubicin water solution and solution of PLGA and Nile Blue in chloroform. The second emulsion was created by adding the first emulsion to the PVA and chitosan oligosaccharide lactate water solution. Next, the as-obtained suspension was centrifuged thrice and thus colloidally stable polymer PLGA nanoparticles were obtained.

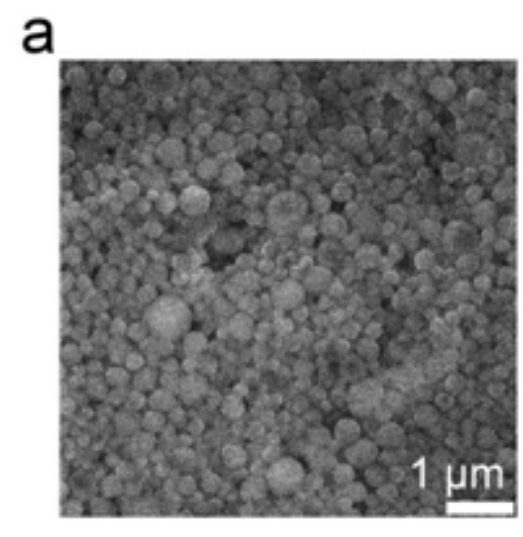

C
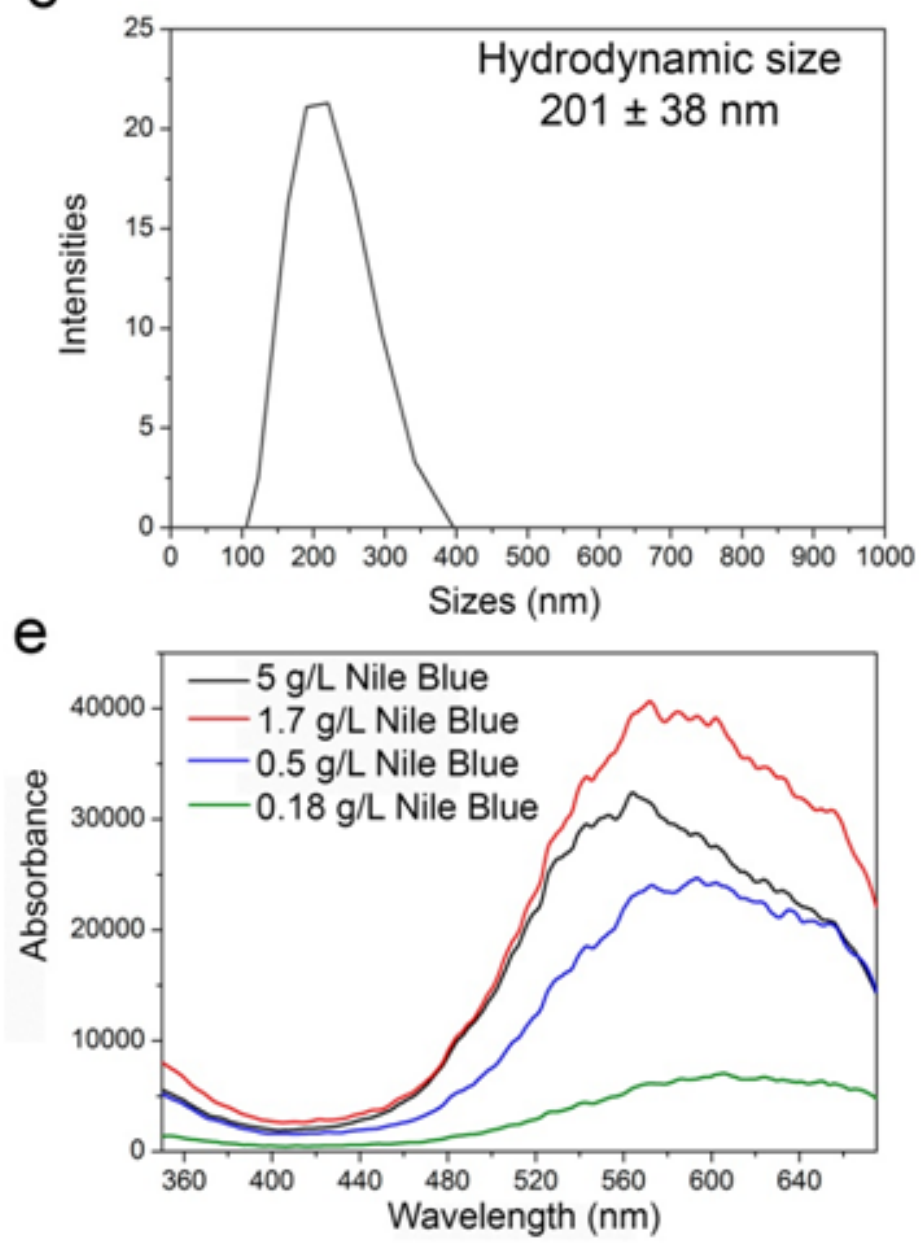
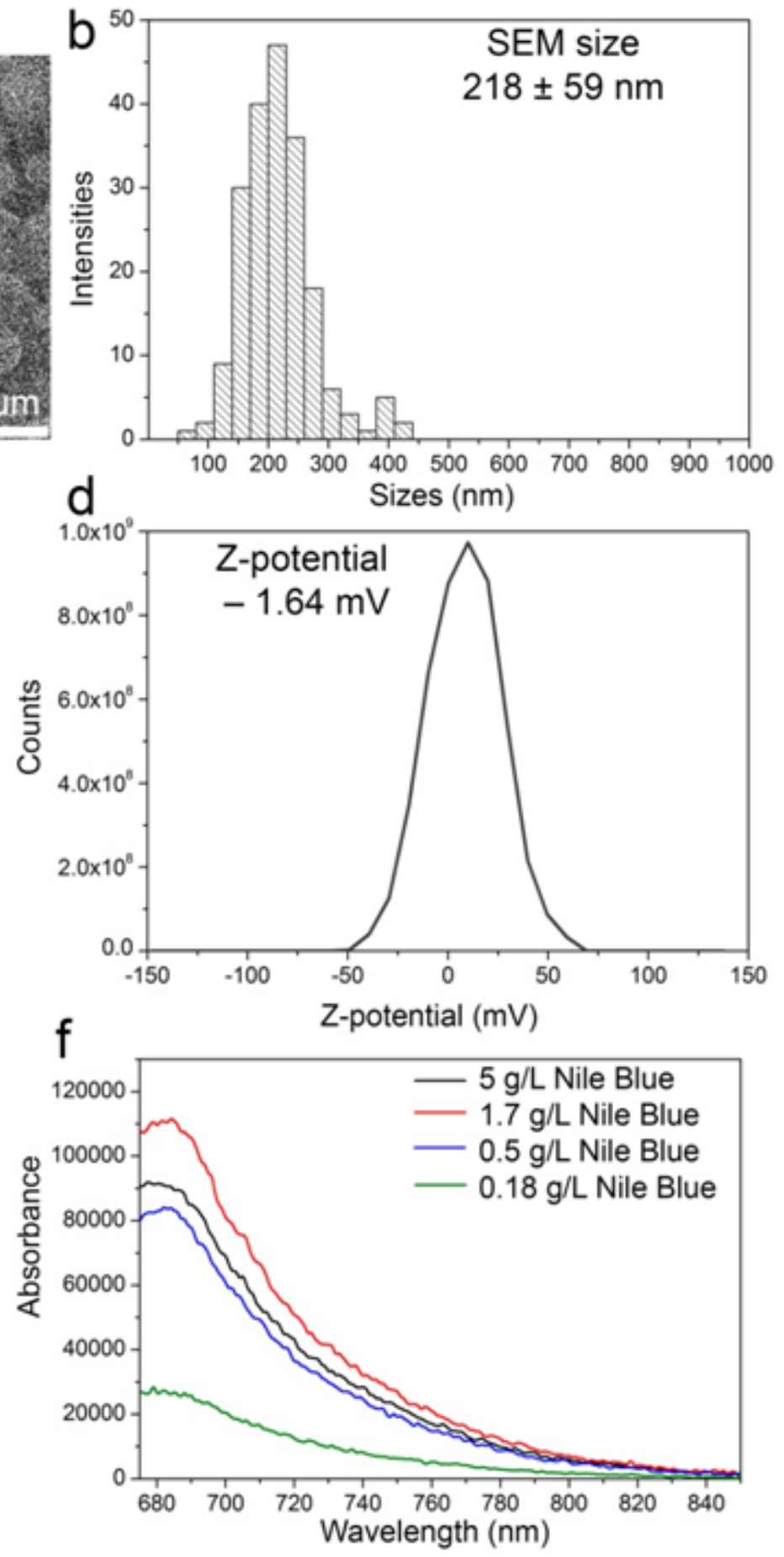

Figure 2

Physico-chemical properties of PLGA nanoparticles. (a) Scanning electron microscopy microphotograph. (b) The physical size distribution of nanoparticles, obtained by image processing. (c) Hydrodynamic size 
distribution was obtained by the dynamic light scattering method. (d) Z-potential distribution of nanoparticles obtained by the electrophoretic light scattering method. (e) The excitation spectra (emission wavelength $700 \mathrm{~nm}$ ) of PLGA nanoparticles according to the fluorescent dye concentration. (f) The emission spectra (excitation wavelength $650 \mathrm{~nm}$ ) of PLGA nanoparticles according to fluorescent dye concentration.

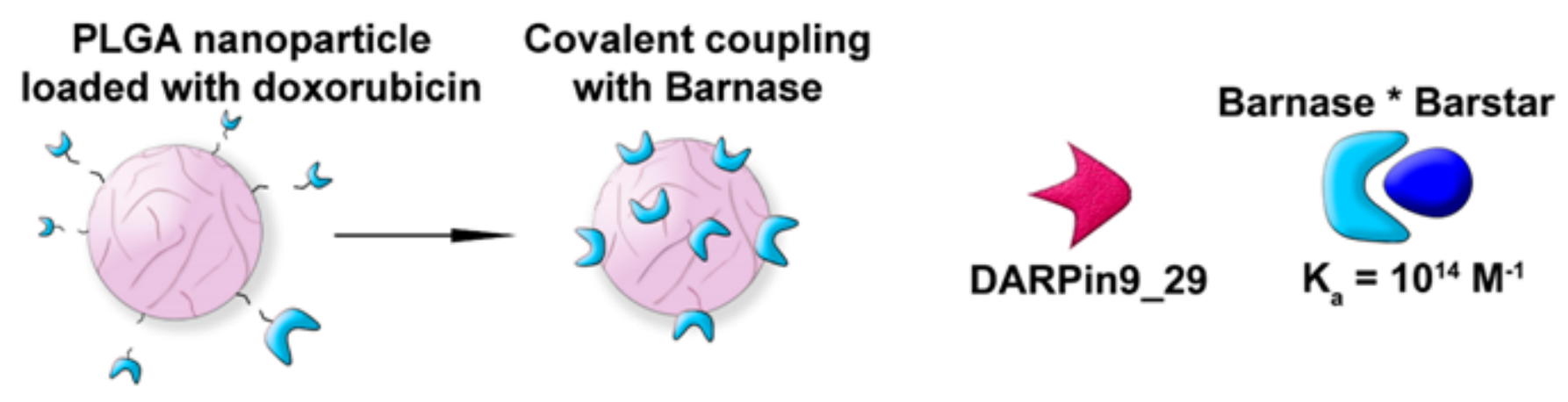

\section{TARGETED DRUG DELIVERY ONE-STEP VS. TWO-STEP}

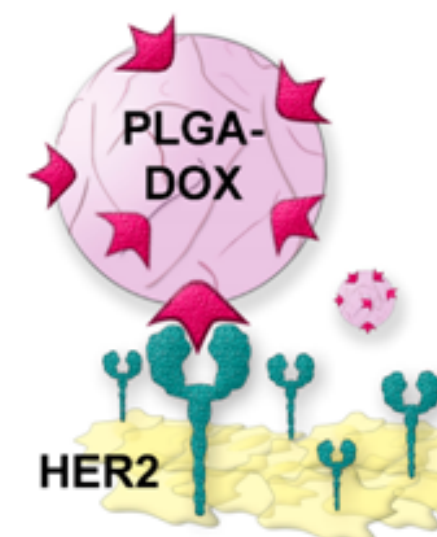

One-step targeting

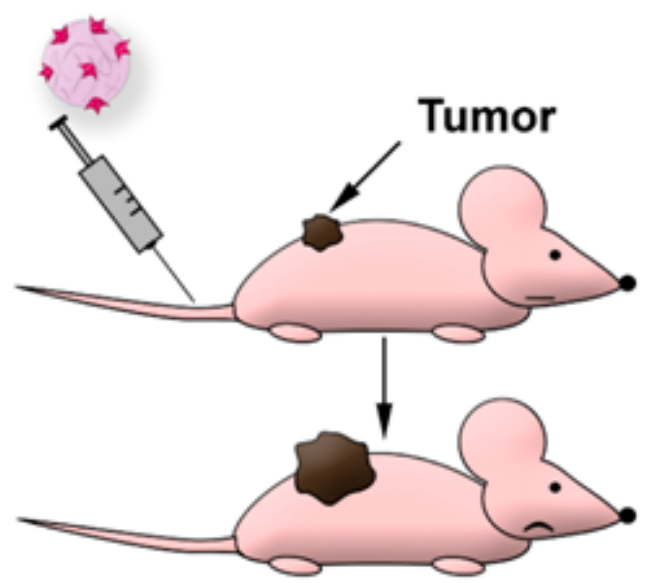

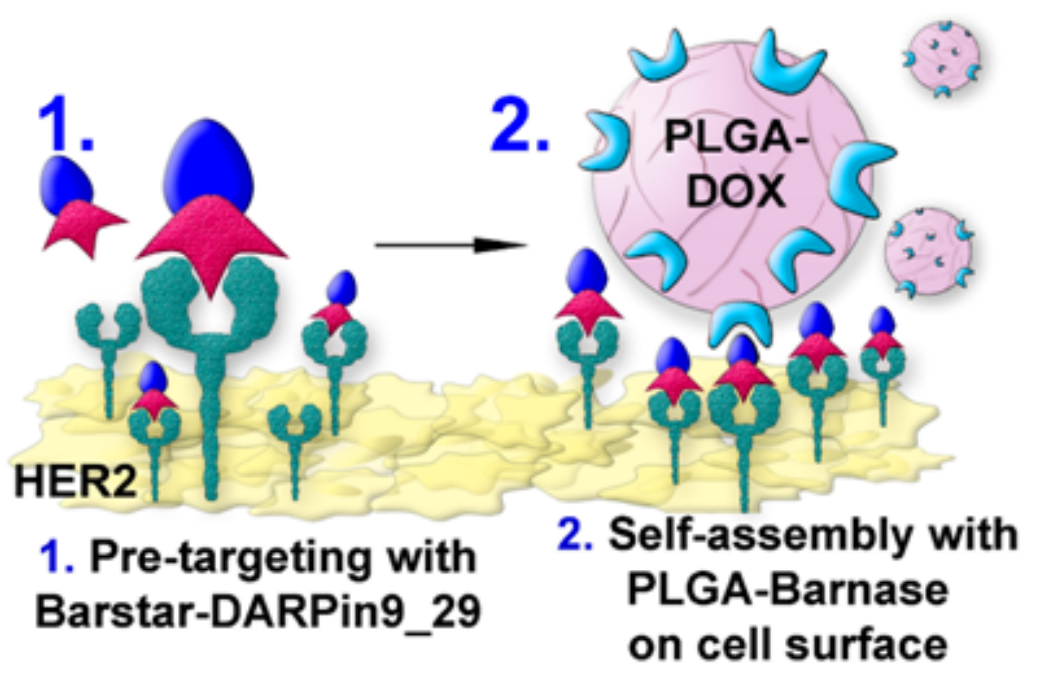

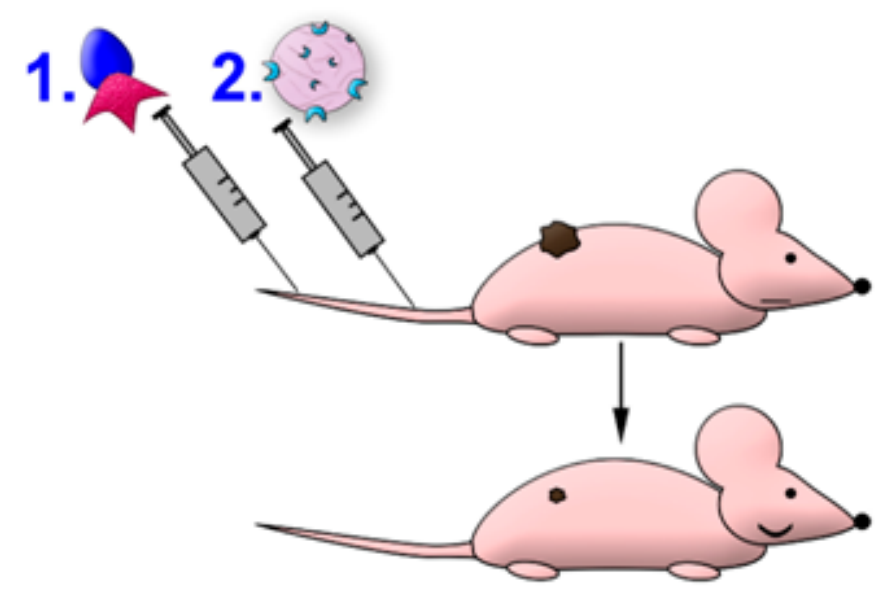

Figure 3 
Scaffold protein-mediated one-step and two-step delivery of polymer nanoparticles loaded with doxorubicin to cancer cells. For the one-step drug delivery system (DDS), PLGA particle is covalently modified with targeting scaffold protein DARPin9_29 that selectively recognizes receptor HER2 on the surface of cancer cells. For two-step DDS, the PLGA surface is covalently modified with barnase; then, the structure is assembled with barstar fused with DARPin9_29. The self-assembly of nanoparticles with scaffold polypeptides using protein interface barnase*barstar for the delivery to HER2-overexpressing cancer cells allows increasing the therapeutic efficacy of chemotherapy-loaded nanoparticles significantly.
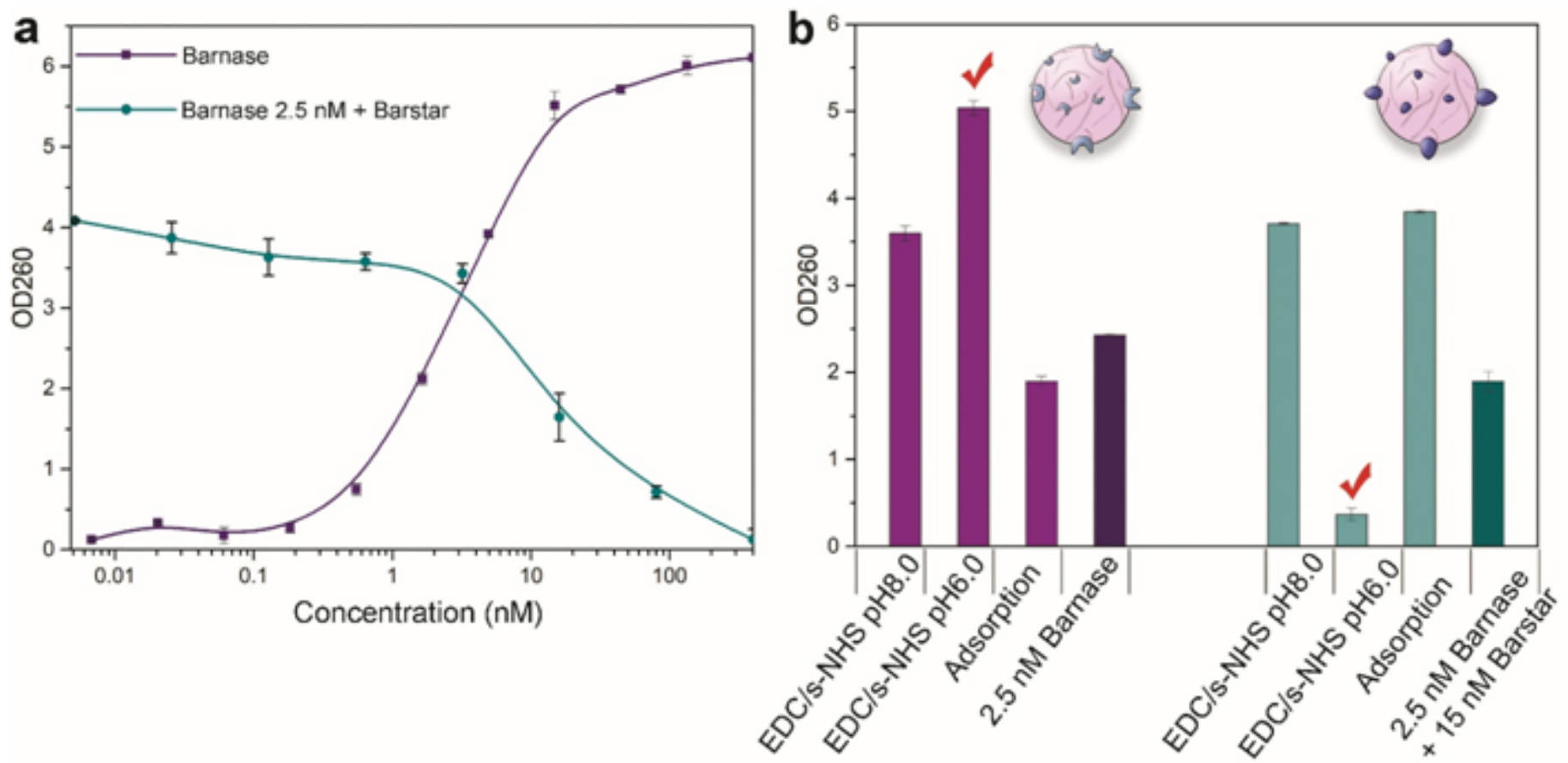

\section{Figure 4}

Functional activity of PLGA nanoparticles conjugated with barnase and barstar proteins. (a) The enzymatic activity of barnase (purple curve) and barstar (green curve) versus protein concentration. Optical density at $260 \mathrm{~nm}$ corresponds to the concentration of free mononucleotides obtained by barnase digestion of yeast RNA (for barnase activity) and by barstar pre-incubated with $2.5 \mathrm{nM}$ of barnase (for barstar inhibition activity). (b) The enzymatic activity of PLGA conjugates with barnase (purple bars) and barstar (green bars). Data is presented for conjugates obtained at pH 8.0, $\mathrm{pH} 6.0$, and by non-covalent protein absorption on the particle surface. Optical density (OD260) corresponded to the concentration of free mononucleotides was measured at a wavelength of $260 \mathrm{~nm}$. 

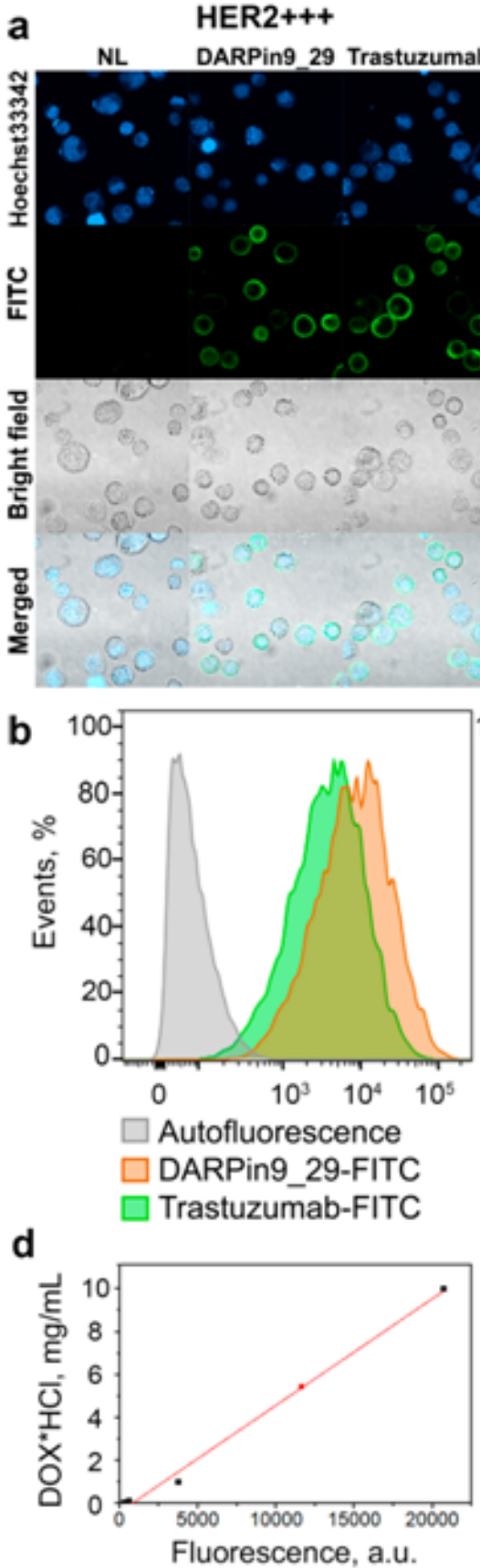
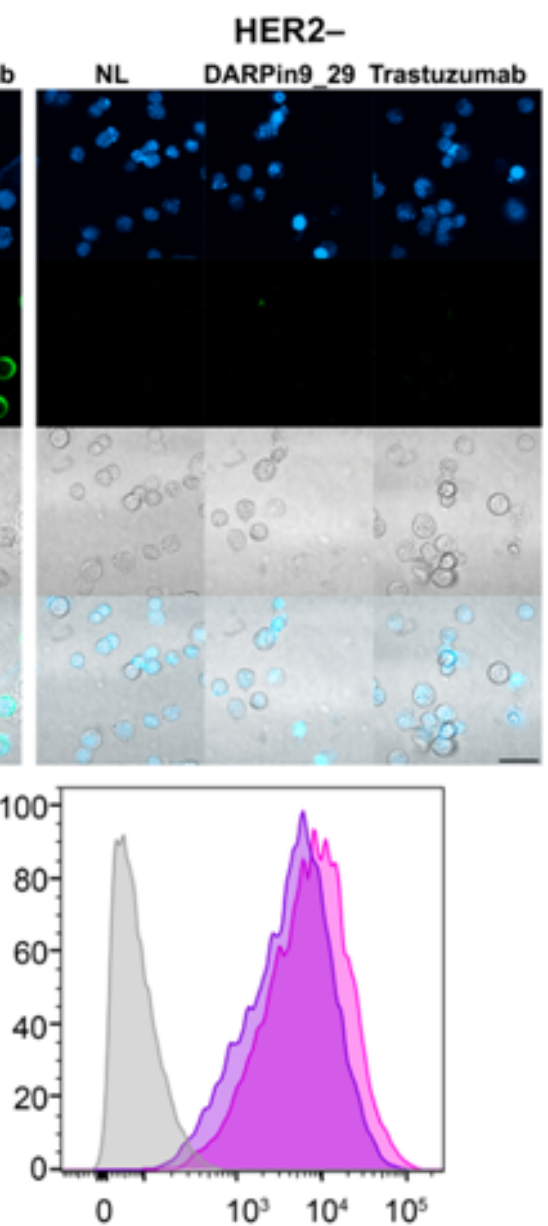

$\square$ Autofluorescence

Bn-DARPin9_29-FITC

Bs-DARPin9_29-FITC

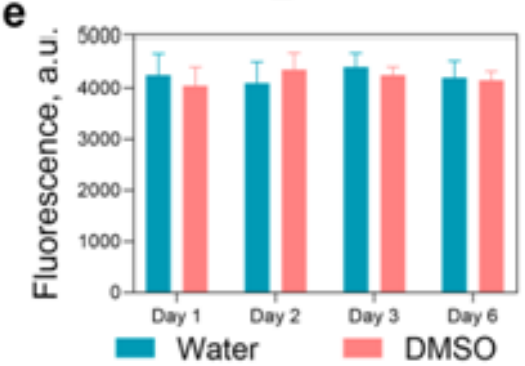

\section{C}

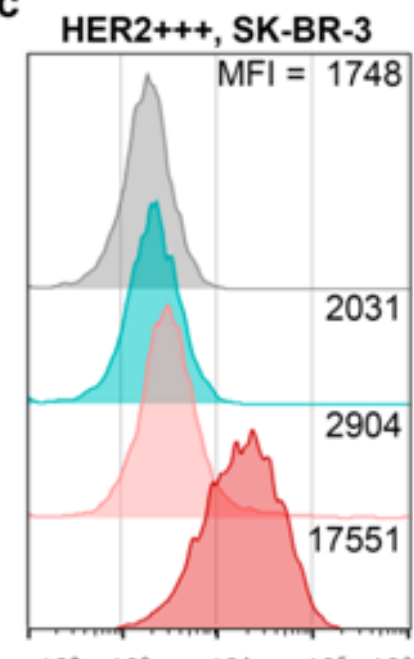

$\begin{array}{lllll}10^{2} & 10^{3} & 10^{4} & 10^{5} & 10^{6}\end{array}$ Fluorescence intensity (a. u.)

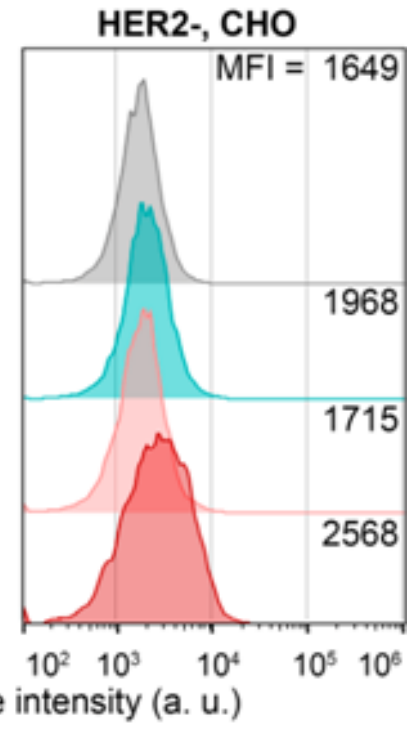

PLGA-Bn*Bs-DARPin9_29 $0.5 \mu \mathrm{g} / \mathrm{mL}$

$\square \mathrm{NL}$ 口PLGA-Bn*Bs-DARPin9_29 $2.5 \mu \mathrm{g} / \mathrm{mL}$

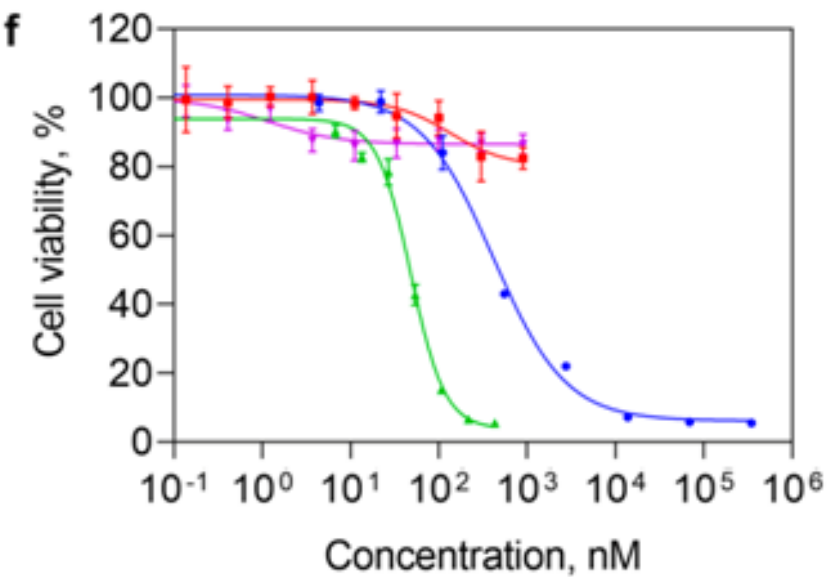

- Free doxorubicin

- PLGA loaded with doxorubicin

$\rightarrow$ PLGA-Bn*Bs-DARPin9_29

- PLGA-DARPin9_29

\section{Figure 5}

Targeted delivery and cytotoxicity of two-step drug delivery system, PLGA-Bn^Bs-DARPin9_29. (a) Confocal laser scanning microscopy of SK-BR-3 and CHO cells, labeled with DARPin9_29-FITC and Trastuzumab-FITC. Bottompanels - bright-field images, toppanels - fluorescent images of the cells

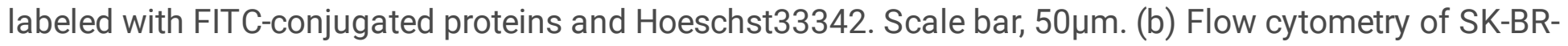
3 cells, labeled with DARPin9_29-FITC, Trastuzumab-FITC, Bn-DARPin9_29-FITC, and Bs-DARPin9_29-FITC in the fluorescence channel FL1 corresponding to FITC fluorescence. (c) Flow cytometry of SK-BR-3 and $\mathrm{CHO}$ cells, labeled with PLGA-Bn*Bs-DARPin9_29 nanostructures in the fluorescence channel FL4 corresponding to Nile Blue fluorescence. (d) Calibration curve for the measurement of doxorubicin* $\mathrm{HCl}$ incorporation into PLGA nanoparticles obtained with fluorescence spectroscopy (excitation $480 \mathrm{~nm}$, 
emission $590 \mathrm{~nm}$ ). The red dot indicates the measured doxorubicin concentration in $1 \mathrm{~g} / \mathrm{L}$ sample of PLGA particles. (e) The stability of fluorescence of PLGA particles loaded with doxorubicin and Nile Blue both in water and in the organic solvent, DMSO for 6 days. (f) Cytotoxicity of free doxorubicin, non-targeted PLGA loaded with doxorubicin and targeted one-step DDS (PLGA-DARPin9_29) and two-step DDS (PLGA-Bn*BsDARPin9_29) based on PLGA particles, obtained with MTT assay.
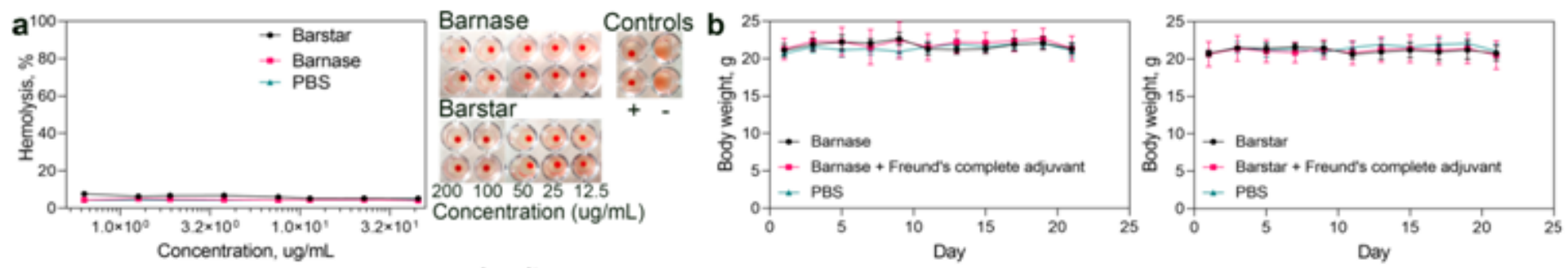

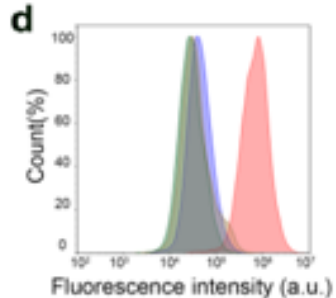

-EMT-HER2 Anti-HER2 lgG-FITC

$\square$ EMT-HER2
EMT6/PAnti-HER2 IgG-FITC $\square$ EMT6/P

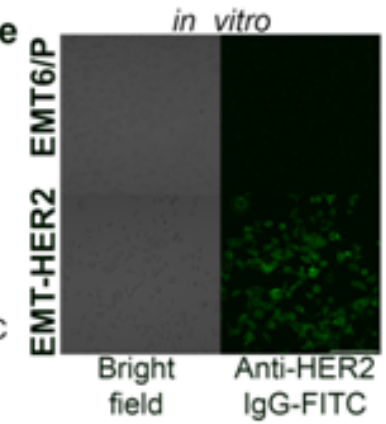

ex vivo
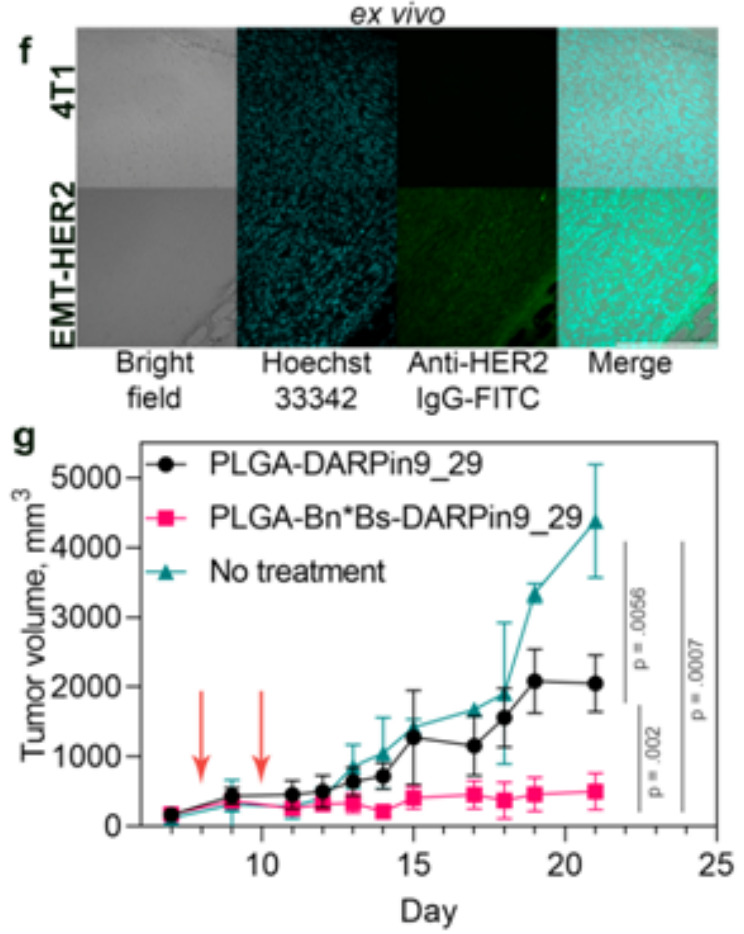
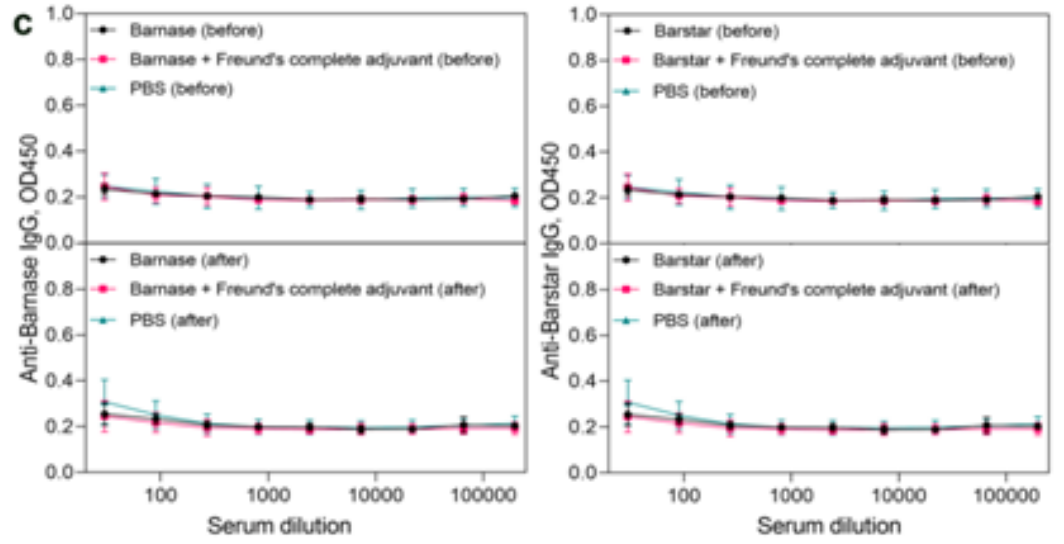

Two-step DDS

1. Bs-DARPin9 29 One-step DDS

h
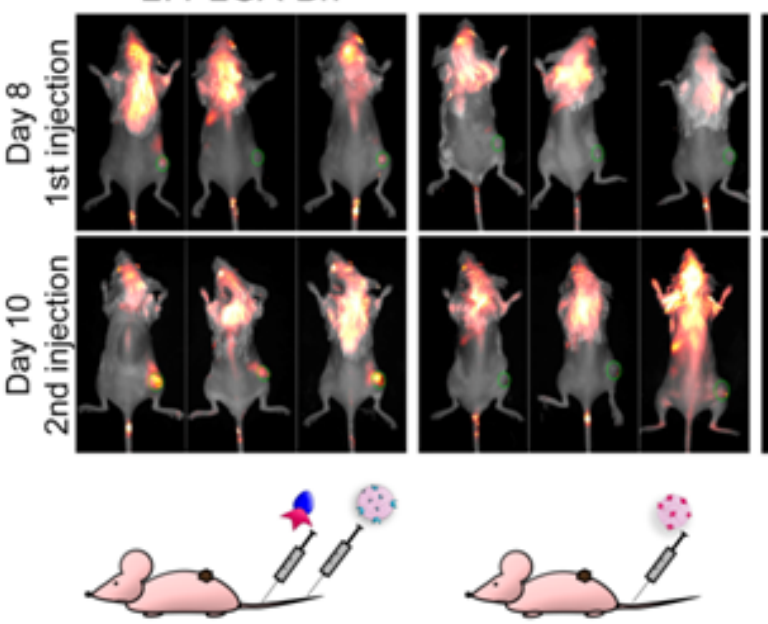

No treatment
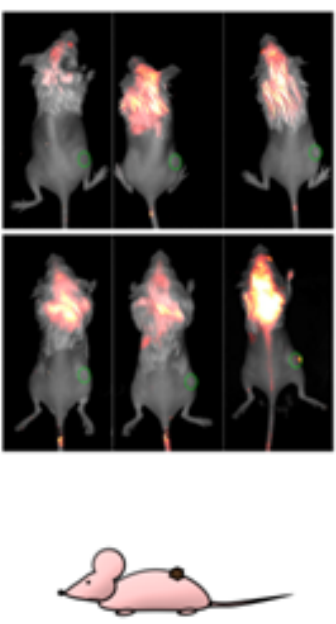

\section{Figure 6}

In vivo performance of two-step targeted drug delivery system viabarnase*barstar interface. (a) Hemotoxicity study of barnase and barstar. The intensity of erythrocyte lysis after the incubation with barnase or barstar at various concentrationsis presented as a percentage of the positive control. A sample 
of erythrocytes lysed with distilled water was used as a positive control, and a sample of erythrocytes incubated in PBS was used as a negative control. The data are accompanied by the agglutination study. RBCs sequentially incubated with rat anti-RBC antibodies (TER119) and goat anti-rat antibodies were usedas a positive control. A sample of RBCs incubated in PBS was used as a negative control. (b) Body weight dynamics after the sequential injections of barnase or barstar for the experimental and control animal groups ( $n=3-5$ mice). (c)Study of a protein-specific immune response for the proteins barnase and barstar. BALB/c immunocompetent mice were used as experimental animals. The graphs show the absorption rate of the phosphatase substrate, corresponding to the quantity of antibodies specific to barnase or barstar, depending on the blood serum dilution in blood samples before and after 7-fold administration of the corresponding proteins. (d) Flow cytometry analysis on cell labeling with anti-HER2 IgG-FITC. Initial EMT6/P and cells with HER2 (EMT-HER2) were labeled with anti-HER2 IgG-FITC and analyzed in the fluorescence channel corresponding to FITC fluorescence. (e) Confocal laser scanning microscopy of EMT6/P and EMT-HER2 cells labeled with Trastuzumab-FITC. Left panels - bright-field images, right panels - confocal images of the cells. Scale bar, $250 \mu \mathrm{m}$. (f) Ex vivo imaging of HER2 expression in EMT-HER2 tumors. Tumors were excised, and cryosections were stained with Hoechst33342 and anti-HER2-FITC IgG followed with confocal laser scanning microscopy analysis in bright field and fluorescence channels corresponding to Hoeschst33342 and FITC fluorescence. 4T1 tumors with no HER2 expression served as the negative control. Scale bar, $250 \mu \mathrm{m}$. (g) EMT-HER2 tumor growth dynamics under the treatment with one-step DDS, PLGA*DARPin9_29 particles, or two-step DDS, Bs-DARPin9_29 \& PLGA$\mathrm{Bn}$. Arrows indicate the nanoagents injections. (h) Imaging of BALB/c mice with EMT-HER2 tumors after the first and second injections of the one-step DDS, PLGA*DARPin9_29 particles, or two-step DDS, BsDARPin9_29 and PLGA-Bn in comparison with the control group. Imaging was performed with LumoTrace FLUO bioimaging system with fluorescence excitation at $730 \mathrm{~nm}$ and $780 \mathrm{~nm}$ long-pass filter, thus registering the PLGA particles fluorescence.

\section{Supplementary Files}

This is a list of supplementary files associated with this preprint. Click to download.

- Supp.png

- Supportinglnfo.docx 